\title{
J出空录
}

\section{1. 化學工業用機械及實驗裝置}

細を硝子管を通る氣䯣の流に對する摩擦系數 毛垈 流速叶の賽驗的目盛決めり不健 (Benton，J. Ind. Eng. Chem., 1919, 11, 693) に鑑み計算によりて日


豫め 2 本の矿子毛管（辰さ各 $120 \mathrm{~cm}$ 、內徑 1.139 及ひ


メタン）㤂通じ恒麼の下に $0.1 \mathrm{ft}^{3}$ の氣體が通過する 時間㤂测定し此の值と毛管の斷面とより流速艻算出す （實驗せられたっ 流速の籍圍は 5-121ft/sec）同時に




さ（mm）にて表はさらつか以て之れる Fanin 氏式 に適礁せしもろ焦めに䨘際流通す万氣體の高さに換算 寸即



$$
\begin{aligned}
& \text { 降下 }(\mathrm{mm}) \times \text { 水の密度 }(62.4)
\end{aligned}
$$

$$
\left(\mathrm{lb} / \mathrm{ft}^{3}\right)
$$

さて Fanin 氏式は $\Delta h=\frac{2 f L u^{2}}{g d}$ にして玆に $\Delta h$ は管艻流過す万流體の菏さにて表はされたる毛管によ 万歷力降下、 $u$ は流速 $(\mathrm{ft} / \mathrm{sec}) 、 \mathrm{~d}$ は管の近德 (ft)、 $g=32.2 \mathrm{ft} / \mathrm{sec} 、 f$ は摩擦因子なり故に此式より流速管 の㺼徑及長さ、氣體り密度、氣體の種類、及流れの潈 度わ種々に變更したる時の膦擦因于れ求めら万今毛管 の物質及流體の種類が定まる時例へば此場合确子毛管 內の秋體流に就ては $f=\phi\left(\frac{D u \rho}{\mu}\right)$ なり玄に $D$ はも


(氣體流入例)、 $\mu$ は氣體の粘度（英國單位即 $0.0672 \times$


の系數と Fanin 式より求めたる摩擦系數 $f$ との關係 古 $\log -\log$ 紙上に圖示す万时仗毛管流速計の目盛々 算的に知り得即与流速㸝に使用せんとする毛管は長さ




密度と粘度とょり系數 $D u p / \mu$ 各算出して上の $\log$ $\log$ 曲線より $f \sigma$ 值求め此值古 Fanin 式に代入



ろなり (Marshall Elliott, Ind. Eng. Chem., 1928, 923)

(融 田)

\section{2. 一 般 化 學}




てイオン及び核の變化か觀測せるに (1) 微柽子 (particle）方發散する白金線の能力は使用につれて減退 寸但し從前より强電流な通過せしもろか或はブンゼン 燈內にて短時間加熱なさば發散能は一晆舊に復す（2） 微粒子の本體は原子分子乃至金屬の微粉の何れなろゃ


觀察不可能なり此ものは時間の經過によりて㠜集し觀 察し得るに至万猫 2 筒の微柽子の衝突全體等の曲折徑 路は超㙷微鏡下に映じ來らず (2)微柽子の數と時間と の關係吕圖示寸万に微粒子數は勿論零時間に於て最大 にして雙曲線に沿ふに次第に減ず此定量的觀測々視覺 と寫蕒との兩者により行ひたるに次の如き關係か得ざ y $1 / n-1 / n_{0}=k t$ 或は $d n / d t=-k n^{2}$ 但し $n_{0}$ は最初に 存在せし核の数 $n$ は任意の時間 $t$ 後の核の數え表は し $k$ は恒數なり因に寫眞による $k$ は平均 $0.15 \times 10^{-8}$ $\mathrm{cm}^{3} / \mathrm{sec}$ にして祝覺に訴へしものは $0.10 \times 10^{-5} \mathrm{~cm}^{3} / \mathrm{sec}$ なり (W. D. Flower, Phil. Mag. 1928, 1084)

\section{(传々木)}

水銀蒸荣の綠色營光 水銀蒸氮の綠色帶罃光 (green band fluorescence) はハウターマンス氏 (Houtermans) にょりて $2^{3} P_{1}$ 狀嶣の分子の興舊に 蹛因す万ものと報ぜら万つも著者はか!万高震動の必


素槽並に青色二ビオル确子板か使用しつ〉鐵又は銅孤


球上に焦點龙合して照射せ万に輝綵線路店蒸氣內の光 りの通路に描きたり然るに静色ニビオル确子方通過し 得万水銀の最短波長は $\lambda 3125$ にして單色光る以て行


磁め得げり (Rayleigh, Nature, 1928, 122, 242)

(估々木)


の燐光に關する實驗、ライス氏の吸收スベクトルに關 
すろ研究、フッド氏の兆化學的に宸酸より舍水岸素合 成結果等死基礎として化學反雇死輻射說によりて硫明 せんとする理論にして次の如き絬論なり(1)化學反應 物の活性化は輻射線の吸收によりて遂行せらろ〉るの にして其活性化に㠫するェネルギーは此等化學反應物 の隐界エネルギーより大なり換言せば一度超活性狀㦔 に荙エネルギーの水準右高为らるく6のなり此超活性 狀㦔と臨界エネルギーとの差は鉒光の根元なり（2）活 性化の機構㳉 2 段に分たる 1 は部分活性化 (partial atcivation) 2 は仕上げ (final activation) なり前者 は $\mathrm{A}-\mathrm{B}+$ の如き錯㿼虑想像せしも即ち $\mathrm{A}$ は其の问 轉エネルギー（rotational energy）施失ひ B は臨界 エネルギーを獲得するものにして此鍇監の安定度は $\mathrm{A}$ の回轉エネルギーの回復にのみ從厤するものなり換言 せば活性叴有する B の自由狀態の生成は最早輻射エ ネルギーの直接行動の支配㤂受けず單に赤外線方吸收 すろAのエネルギーの大きさにのみ左右せらろかくて 赤外線は重要なる役割か演ずろものなろが前記錯艮の


最早測定至難となるべき點に這入ろべき最高極限とる 認め得へしし (E. C. C. Baly, J. Soc. Chem. Ind., 1928, 47, 914)

(伀々木)

ニッケル及びコバルトに對するラチウムの作用 = ッケルとコバルトの既知混合物各含む㿼類溶液中に臭 化ラヂウムか容れたる封管か䝮垂せしめて $\beta$-線か働 かしめたるにコパルトよりニッケルに轉移せるが如き 哧果方得たり使用したる臭化ラダウムの量は $0.1 \mathrm{~g}$ に 過ぎさりしか以て 8 年 7 月或は 5 年 5 月の長年月る要 したり (Massol et Daubian-Delisle, Bull. Soc. Chim., 1928, 935)

(渎杂)

無嘰弗化物の $25^{\circ} \mathrm{C}$ 亿於ける水に對する溶解度 使 用したる弗化物は $\mathrm{CaF}_{2} 、 \mathrm{MgF}_{2} 、 \mathrm{SrF}_{2} 、 \mathrm{Na}_{3} \mathrm{AlF}_{6}$ 、 $\mathrm{PbF}_{2}, \mathrm{CuF}_{2}, \mathrm{FeF}_{3} 、 \mathrm{BaF}_{2} 、 \mathrm{LiF}, \mathrm{MnF}_{2} 、 \mathrm{AlF}_{3}$ 、 $\mathrm{CdF}_{2} 、 \mathrm{CoF}_{2} 、 \mathrm{ZnF}_{2} \bullet 4 \mathrm{H}_{2} \mathrm{O} 、 \mathrm{NiF}_{2} 、 \mathrm{NaF}$ の 16 種に して $25^{\circ} \mathrm{C}$ に於て水て對す万溶解度忘測定し更に此等 の弗化物の飽和溶液の $\mathrm{pH}$ 值㤂求めだり三の弗化物 の溶解度及び $\mathrm{pH}$ 值か表示すれば下の如し

\begin{tabular}{|c|c|c|c|c|}
\hline 化合物 & 分子式 & $\begin{array}{l}\text { 溶解度 } \\
(\mathrm{g} / 100 \mathrm{cc})\end{array}$ & \multicolumn{2}{|c|}{$\underset{(\mathrm{g} / 100 \mathrm{cc})}{\mathrm{F}_{2} \text { 含量 }} \mathrm{pH}$} \\
\hline  & $\mathrm{CaI}$ & 0.004 & 0.002 & 6.4 \\
\hline $\begin{array}{l}\text { クライオラ1 } \\
\text { 卜(合成的) }\end{array}$ & $\mathrm{Na}_{3} \mathrm{AlF}$ & 0.061 & 0.033 & .7 \\
\hline $\begin{array}{l}\text { 弗化テル } \\
\text { ミ゙ゥウム }\end{array}$ & $\mathrm{AlF}_{3}$ & 0.559 & 0.379 & 5.2 \\
\hline 弗化ナト & $\mathrm{NaF}$ & 4.054 & 1.834 & 7.9 \\
\hline
\end{tabular}

(R. H. Carter, Ind. and Eng. Chem., 192S, 20, 1195)

(久保田)

アセチレン亿對する光の作用 1898 年 Hempel 氏 (Z. Angew. Chem., 11, 53) はアセチレンの分析に 際し、アセチレン吉硫酸性硫酸䑪溶液に吸收せしも万


ン中に含有さら万〉燐化水素の光化學的分解に基因寸


ン杂原料として純粹なるアせチンンか作り确子及石英 器中に於て日光に作用せしめたるに何等の綧化方認め さりき次に石英器中にて水銀登にて照射せるにアルデ 七ド重合物と考へらろい如き物質な生じたり沃に特别 の装置に依りて数回液化、蒸溜ね反覆して得たる空氣 及濕氣它完全に除去せる極めて純粹なるアセチレンる 用ひ同樣に賽驗せるに波長 $300 \mu \mu$ 以下の光楾に依り




成物は少量なる䈍其の組成明ならざるも其は多くの有




り (H. Reinicke, Z. Angew. Chem., 1928, 41, 1144)

(田 代)

アセチレンと硫黄との反鹰 Meyer Pandmeyer 雨 氏は（Ber., 1883, 16, 2176）ア七チレン中にて硫黃 京熱しチォフェーンと思は万ろ物筫か得たれども此物 な單離する能はざり沃に Capelle 氏 (Bull. Soc. Clim. 1908, 4, 150) 及 de Coninck 氏 (Bull. Acad. roy. Belg., 1908, 305)等は生成物中には單に二 硫化宸素とチォフェーンが存しこれに件ひて韭臭の おろ物質の存在る定性的に認めたり最近に Briscoe 及 Peel 雨氏 (J. Chem. Soc., 1998, 1741)はチオフェー ンも多分合成さ万ろが主耍なる反製は二硫化炭素の生 成なり洏して使用せし硫黄の77\%は之等の縮合物の 生成に關與し殘りの硫黄は硫化水素と宸䋜との生成に 消䩀さ万万ものとさり著者等は $325^{\circ} \mathrm{C} 、 500^{\circ} \mathrm{C} 、 650^{\circ} \mathrm{C}$ の三種の反雔潜度に於けろアセヂンと硫黄との油狀 縮合物に就て其の主要生成物右定量的に研究し次の絬 果良得たり



(J. B. Peel and P. L, Robinson, J. Chem. Soc., 1928, 2068)

(你 谷) 


\section{3. 䉓氣化 學}


照 ニトロベンゾールにベンッアミドと泉素の分子當


にして $\mathrm{C}_{6} \mathrm{H}_{5} \cdot \mathrm{CONH}_{2} \cdot \mathrm{Br}_{2}$ として $52 \%$ まで濃度とと


りて圖示すれば $35^{\circ} \mathrm{C}$ に於ては稀釋度約 $900 \mathrm{cc}$ の所に


トロペンゾールに县㨞方溶解し此溶液が゙ンッアミド 各以て電尊度湖定各行へろに $\mathrm{Br}_{2}: \mathrm{C}_{6} \mathrm{H}_{5} \cdot \mathrm{CO} \cdot \mathrm{NH}_{2}$ $=1: 1$ の時に制然たろ終點虎示し $\mathrm{C}_{2} \mathrm{H}_{5} \cdot \mathrm{CO} \cdot \mathrm{NH}_{2} \mathrm{Br}_{\tilde{6}}$ 即 Laurentsche Bromid なろ化合物の存在するる 示さり此溶液か電解するに㓌極にはベンッフミド結晶 沈着し陽極には臭素進離せり此場合の分解電㨫の测定


解生成物が復極作用右有寸るによろなるへし是等の點 より考ふらに此溶液中に於ては $\mathrm{C}_{5} \mathrm{H}_{5} \cdot \mathrm{CO} \cdot \mathrm{NH}_{2} \mathrm{Br}_{2}$ な 万化合物各狋しII. 其が解離し.て $\mathrm{C}_{6} \mathrm{H}_{5} \mathrm{CO} \cdot \mathrm{NH}_{2}{ }^{--}$及 び 2Brーなろイオンか生ずな玨此溶液の濃度異万物 2


論數に近き價艻得たりり唯其方向が理諭と反對なり (W. Finkelstein und O. Kndra, Z.f.phys. Chem., 1928, 131, 338-46)

(岡俊平)

一對の同一金屬電極を使用する雪瓷滴定法 白金镜 金せろ黑色の白金板か㨁火にて加熱し欧色とせろ6の と普通の白全板とな適當の距離に相對せしめ此か湳定 すべき液に入れ雨極とし雨極か電暦部（30ミリヴォル


次の如寻種々の場合に消足な万結果㤂得けり（1）過 マンガン酸カリウムによろ第一鐵監の定量 (2) 過マ ンガン酸カリウムによろフェロシアン監の定量 (3) 過マンガン酸カリウムによ万苳酸の定量 (4) クロ一 ム酸によ万第一溨監の定量 (5) 系素酸監によ万亞䂣 酸監の定量 (6) 次亞硫酸蹟によ万沃度の定量（E. Müller und H. Kogert, Z.f. phys. Chem., 1928, 136, 437-45)

(岡俊平)


各行子雨極としては白金等の同一金屬針企䘮適當に離




万万示度を讀み示度最大な万點か終點とす第二法に於 ては溶液の器器占一部分硂子管等にて仕切り其内外に 雨極各置く敵定液は外の部分に滴下し充分混和せ万後
外の電極にふれ更に管內に浸入し內の極に觸る万如く 寸湖定の終點は第一法と同じく電崖計の示度最大なる 點々取万第一法は測定に時間方装せ奴特長あれど非常 に正磪とは云ひ難し第二法はやや時間か㠫すれど充分 精磪彷y (E. Müiller und H. Kogert, Z. f. phys. Chem., 1928, 136, 446-59)

(岡俊平)

篮單教る電筑滴定法及び電溳度滴定法之其窟用 電


めて平易なる說明死行ひ其應用の實例多數る上げたる 講義なり特に染料工場に於け万應用の賽例虏多數に警 ぐ (T. Callan and S. Horrobin. J. Soc. Chem. Ind., 1928, 47, 329-43T)

(岡俊平)

\section{4. 酸、アルカリ及肥料}

㞸素に依る燐酸三石灰の摆元 珪酸か用わず炭素の みにて燐酸三石灰の還元死行ひ其正碓なる條件る求为 たり（1)燐酸三石戻る化學的純粹なる物と然らざる物 と艻用ひ石墨油煙墨砂糖製炭素宸素粉(Carbon flour) 等の還元劑と共に孷素製管の電氣爐に入れ堂素瓦斯方 $1685 \mathrm{cc} / \mathrm{min}$ の一定速度れ以て造り還元を行ひしに何 れも同一絬果方得たり (2)還元劑は砂糖製炭素炭素粉 等が稍有效なる6他の欧分政导炭素類る大體に同一程 度の数果吉收めたり(3)㳨度 $1150^{\circ} \mathrm{C}$ にて反應初まり $1325^{\circ} \mathrm{C}$ にて 1 時間行子小或は $1500^{\circ} \mathrm{C}$ にて 10 分間 行ふが最も直き條件なり(4)各溫度の反應速度は何れ も試料の厚さ $1 \mathrm{~cm}$ 增す永に急激に減少し又上層は最 も主く還元進むも中央部が最も反應遲し是れ試料の熱 傳導度惡しきが碥なり (5)窒素の流通速度が $245 \mathrm{cc} /$ min の時 $366 \mathrm{~mm}$ の㭽力にては燐 $56.7 \%$ 方生ずろが $1240 \mathrm{~mm}$ の俩力にては $34.8 \%$ に減少す然し 速度か $1685 \mathrm{cc} / \mathrm{min}$ に早めると塑力れ $655 \mathrm{~mm}$ よ $1122 \mathrm{~mm}$ に 變化する6份燐の收率は同一值方示せり（6)殘渣中に 燐化石灰は $1250^{\circ} \mathrm{C}$ にては生ざざるも $1500^{\circ} \mathrm{C}$ を超人 ろと $0.17 \%$ 方生ずろに到万（7)反應溫度に於けろ固相 の燐酸三石灰は幾分かの分解展方有し過剩の炭素㤂加 一たる時反憵柱急に促進せ 万万即 $\mathrm{Ca}_{3}\left(\mathrm{PO}_{4}\right)_{2} \rightleftarrows$ $3 \mathrm{CaO}+\mathrm{P}_{2} \mathrm{O}_{5} ; \mathrm{P}_{2} \mathrm{O}_{5}+5 \mathrm{C}=5 \mathrm{CO}+\mathrm{P}_{2}$ の二階段の反應 ななすと推定し得是等の結果より $125^{\circ} \mathrm{C}$ と $1400^{\circ} \mathrm{C}$ K 於け万還元の速度俰數方算出せり（8）1500 $\mathrm{C}$ 达の溫


の石灭は $3 \mathrm{Ca}_{3}\left(\mathrm{PO}_{4}\right)_{2} \mathrm{CaO}$ 㤎作万 6 是れ亦岸素によ り還元せられて酸化炭素叴生ず是等の酸化宸素は何れ 6燐酸三石区に働きて還元作用占な寸（Ind. and Eng. Chem., 1928, 1204-10) (七 井) 
監酸の工場に於ける唄藏荤搬及使用法 本報告は工. 場にて媐酸占取投了場合の方法及器具る。迅べ之に使用 寸万種々の酎酸材料名記し各利害得失叴批制し向工場 設計及器具取扱に際し注意すべき點ね記逨せり䜿酸眝 藏槽としては從來磁器、タイルか以て組立てたるるの、 矿子振、珐燳引のタンク使用せら万されど何れも建設 費高く脆弱なる缺點あり最し近代式はゴム張のタンク


易かりしる現今は相當滿足な万成績な示せり價格は中 庸にして硬質の方幾分策價なり木製タンクは比重 1.10 までの酸に對しては良好なりそれ以上はピッテ、アス ファルト或はパラフィンか染付寸著者はこの最後か 推獎す總てタンクは側部及底部に開口る附せず酸流出 はサイフォンか以てするな良とす酸輸选には運搬活、 重力法ポンプ法、空氣䑏这法等あり 後2者は最も迅速 11 . 磪實なり空氣によるものは㲘通アシッドェッグにして ポンプにはセントリフューガル、ヒストン及皮ギヤーの 3 種あり近時は何れもゴム張の鐵方使用するものが最 も優良なりとさら万酸輸秐用の管は砷子、磁器、タイ ル、硬質ゴム、ゴム内張の銅鐵及ゴムホースが使用す 工場が多少振動す万場合前 3 者は不可にして䈍通はゴ ム張が最適目廉價なりされど極めて振動激しき時はゴ ムホースな用ひるの外なしバルブは磁器硬質ゴム及ゴ


雔タンクは磁器、珐琪鐵木製及硬質ゴム內張のタンク が使用せら万軟質ゴム內張タンクは $65^{\circ} \mathrm{C}$ 以下の酸に は使用し得多くの反應は或䍒度㤂必要とすべく加熱法 としては㨁接䓠氣吹込或はジャケットの法による磁器 は鬼裂各生ずろ危險あり琣瑯引は小規模の場合最も適 當なり大規模には木製或は硬質ゴム張鋼鐵製タンクは 良好にして何れる 2 年以上の使用に耐ゆ耐 $\mathrm{HCl}$ 金屬 として市場にあ万硅素鐵、マンガン銅等の合金は絕對 のものには非ずして時々取換を毙し又腐蝕物が酸に混 入し有害なる影響え來すへし (Sidney Schein, Chem. Met. Eng., 1928, 673)

(俈 野)

\section{6. 鑛物、治金及金工}

空氣之接臅して愹融せしめし Ag-Cu 合金のカ價の

烥化 $\mathrm{Ag}-\mathrm{Cu}$ 合金各空氣中にて愹融し置加 $\mathrm{Cu}$ が 次第に酸化して力價が增加す万事は鑄造所に於て知 5 れし事なり著者の實驗に依らば此の結論は正しからず


$1 \%$ ब $\mathrm{Ag}$ 各含吉金方 $1000^{\circ} \mathrm{C} に 2$ 時間保てば力㵋 は賭加し 73.5-74.4\%となる (b) $70.6 \%$ の $\mathrm{Ag}$ 吕念もものな2時間 $1300^{\circ} \mathrm{C}$ 附近に 保てば力價は次第に減少し $70.2 \%$ となる即与（a）に ては增加し（b）にては減少す其は二つの相反す万現 象の起万媱にしてて Cu の酸化と $\mathrm{Ag}$ の揮發度なり (a) にては $\mathrm{Ag}$ の捙發少く $\mathrm{Cu}$ の酸化学るしく $1300^{\circ} \mathrm{C} に$ ては $\mathrm{Ag}$ の揮發度は塯大寸万も $\mathrm{Cu}$ の酸化度は $1000^{\circ} \mathrm{C}$ の夫れより著万しく大ならず從つて此の中間溫度


にて磪めたりり (Guichard, Clausmann et Bilon, Bull Soc. Chim., 1928，43-44，752）(宇 野)


硫に重裂にしてH.つ「マスタード」瓦斨の製造にも使










水と反雔寸ろ二つの化學方程式に於て何れの場合にも 籃酸が瓦斯狀となりて發生し之が最も激烈なる腐触作 用叴呈することる指摘せり終りに監化硫黄の麻触作用 の文献中興味おろもの 6 種店强示せり (Ellery $\mathrm{H}$ Harrey, Chem. and Met. Eng., 1928, 35, 684)

(定 方)




は頗万多し其理由とする所は前者の被䨱が後者のそれ に比較してょり純粹なるが篇に低るものとし佾一般的 考察より金屬中の不純物は腐蝕方促非するものと信じ たり藷者は以前に Zn の腐蝕に關し研究死行ひナる万處 Zn の腐蝕右左右す万裂素はその中に含有せら万い不 純物に必ずしも依ろものにむらざろ事或は大氮の営の 腐蝕の行程は腐蝕の結果生成さ万物質の溶解度、傳䆃 度並びに大氣の滋度等に主として影䇾されろ事、唯遊


大する事等か知りたり以上の事實よりして Znの腐触 に於了研究さ万條件方引用し電解亞鉛鉸鋼 (A) が榦


て次の如く實驗せり試料の鋼板は次の如き成分なり $\mathrm{C}=0.15 \% 、 \mathrm{Mn}=0.13 \% 、 \mathrm{Si}=0.58 \% 、 \mathrm{P}=0.042 \%$ 、 $\mathrm{S}=0.042 \%$ 大き $3 \mathrm{in} . \times 2$ in.のものか作り之れらは 總て工業會社の實際的操作に依りて雨種の亞鉛錗金死 されだるものなり鍍着亞鉛量（A)に於て $1.3 \mathrm{~g}$ (B)に 於て $1.5 \mathrm{~g}$ にして其の本均厚さは（A）は $0.0010 \mathrm{in}$. (B)は 0.0012 in.なり令雨者の鈸着厤か考察するに 
（B）は第一純鐵尿第二鐵やの $\mathrm{Zn}$ の固溶體第三固溶 體よりも Zn に富めろ $\mathrm{Fe}-\mathrm{Zn}$ 化合物層第四表面層の 四曆に區分されるも（A）はえれとは全然異なり最し 簡單なる純 $\mathrm{Zn}$ 畨よりなろものなり双て各種の場合の 腐蝕に依乃三包平均減量っ見乃に下の如し 150 日間戶 外懪露後の減量 (A) $5.14 \mathrm{mg} / \mathrm{in} .^{2}$ (B) $2.97 \mathrm{mg} / \mathrm{in} .^{2}$ 、 $0.5 \% \mathrm{KCl}$ 溶液 $1 l$ 中に 1 in. 丈け 20 日閒浸漬後の減 量 (A) $16.9 \mathrm{mg} / \mathrm{in}^{2}$ 、(B) $13.0 \mathrm{mg} / \mathrm{in} .^{2}$ 、浴槽に 200 日 間曝露後の減量 (A) $1.37 \mathrm{mg} / \mathrm{in} .^{2}$ 、(B) $1.35 \mathrm{mg} / \mathrm{in} .^{2}$ 、




$\mathrm{SO}_{2}$ 右含有せしめて污濁せる大氣にすれば一愿早? 庥蝕す何孔も（A）の減量大なり $0.5 \% \quad \mathrm{H}_{2} \mathrm{SO}_{4} 100 \mathrm{cc}$ 中に浸漬後の減量 (A) $83.0 \mathrm{mg} / \mathrm{in} .^{2}$ 、(B) $30.6 \mathrm{mg} / \mathrm{in} .^{2}$ 、 以上總て发通じ（A）の娍量は（B）の夫ょり大なる


とな賽監せり (W. S. Patterson, J. Soc. Chem. Ind, 1928, 47, 44, 313)

(定 方)

\section{8. セメント及建築材料}

枯瓦の有孔度の比較 煉瓦中に存在寸万多數の小孔


射 (2) 傳導及び (3) 對流に依ろと雖も輻射に因ろもの は絕對溫度の 4 乘の差に比例す万な以て最も影響大な y 今兩端の涓度差考 $\mathrm{T}_{1}-\mathrm{T}_{2}$ とすれば $\mathrm{T}_{1}-\mathrm{T}_{2}$ の小な 万時は輻射に因乃熱傅導の割合は $\mathrm{T}_{1}-\mathrm{T}_{2}$ に比例す而 し此の值は 2 孔の小なろ程小となるも (F. H. Schofield, Dictionary of Apptied Physics, Vol. 1, p.




曲線に依りて表はさろ可し 有孔度の湘定圶煉瓦中の 小孔より空来を逃れしめ單位體の煉瓦より單位丝力差 に對して煉瓦方通過す万筀氣の量る以て測万時はPoiseuille の方則る用ひて 小孔れ同一面徑の多數の毛細 管と考へたろ時の管の牛嘼及び數か以て有孔度か表は すを得へし著者の得たる結果は次の如し



此の結果に依れば熱傅導の最も良好なるカーポランダ ム煉㼛と球落土とは有孔度殆ど同樣なり次に著者沈カ
一ボランダム煉瓦の表面に有せる釉藥㤂除去せるに $r=0.0030 、 N=753000$ 々得たり然れ共著者は珠藻土の 如き多數の開塞孔ね有さ万ものは有孔度の测定に此の 方法の用ふ万可らざ万事放指摘せり（G. J. Easter， J. Am. Cer. Soc., 1928, 11, 764) (澤 井)

\section{9. 石油及アスファルト}

ターピン油の人エ的老化の㸴究 タービン油の老化 な人工的に促進させその酸败度方見ろために種々の油 方 $100^{\circ} \mathrm{C}$ 皮び $120^{\circ} \mathrm{C}$ に 70 時間加热し酸素により酸 化しその酸㵋、タール偵、アスファルト含有物等か測 定せり觸媒としては鐵、亞鉛、眞踰、ホワイトメタル 等方用ひたるに解媒右使用さざる場合に比し著しくそ の酸败度芜塯し殊に高浛 $\left(120^{\circ} \mathrm{C}\right)$ にて行子時はその 影響大にして中にも銅为含屯金屬は最も有效にその作


油につきその影響か見けるに一般にロシヤ產の油はこ


ことょり著者は油の酸化促進試驗に於て觸媒として金 屬各用ふろことの重装なるを述べHつこのことは各種


言せり (Reinhold Schmidt, $Z$. angew. Chem., 1928, 41, 1197)

(山田)

オイルアスファルト及タール アスファルテン及び 廢酸古除きた万後 Fullers earth から中性のタールね 抽出せるにこのタールは不安定にして其成分は $\mathrm{C}_{\mathrm{n}}$ $\mathrm{H}_{2} \mathrm{n}-\mathrm{m} \mathrm{O}_{\mathrm{p}}$ に相當せり侕して玆に於ける $\mathrm{n}$ は 19 乃 至 55、m は 9 乃至 33、 $\mathrm{p}$ は 2 乃至 3 なり之れ等の 混合物は polycyclic にして double bond 有する にしても一個以下なり此等のものは硫酸に溶解し硫酸 と混合物炛作乃ものの如し（A. N. Sachanov and N. A. Vasilev, Neft. Choz., 1928, 13, 334-339)

(市川)

カーボンブラック (1) 揮㗶性成分 Carbon black


ず、磪かなことは不明なれども之等の瓦斯は單に吸收 され居万ものの如し之等の揮發性成分は箵謨に混せ゚て ヴァルカナイズ方行ふ場合に於てカーボンブラックの 補强力に重大なら關係方有すかくの如くにして生ず 挥發性成分は滋度が $400^{\circ} \mathrm{C}$ より $955^{\circ} \mathrm{C}$ に上昇するに


斯の量も少し $955^{\circ} \mathrm{C}$ に一旦熱せるカーボンブラックは 最早や吸滋性各有さず酸素は元素の狀態にて存在し岸 素の酸化物は反應生成物なること明かにして水素汢最 
後に發散する瓦斯なりカーポンブラックか製造する場 合に注意すべきは揮發物が護謨の抗張力に影慜するが 故に其の一定量杂必要とす揮發物が Solid tyres 方破 瓌する原因になることは全然考へられず而して護謨と 混合す万場合瓦斯が一つの減摩劑となろな以て揮發物 の餘り少き6のは過量の熱方發生するる恐れあり(C. R. Johnson. Ind. Eng. Chem., 1928, 20, 904-908)

(市川)




深々釜底に薄く流動せし内置き之れに輕油の蒸氣を注


この液體の中に數本の管か埋め置き之れ等の管の中に 水銀の煮氣杂通して熱寸ろものなり斯の如くする時は 强粘度の潤滑油及輕油は溜出す万か以て之れ等方别々 に凝縮ぜしも然らば後には優良なるアスファルトのみ 右殘丁 (A. E. Pew, jun., Assr. to Sun Oil Co., U. S. P. 1, 675, 462, 3. 7. 28. Appl. 22. 12. 26)

（市川）

アスファルト、タール等の乳罚の製造 粉狀或は膠狀 の鏡物質とアスファルト或はタールと混じ之れに曹遘 或は加里石醶より成万乳化劑な加一最後に 1-8\%の市 販のオンインか加へて一ツのパテな造る斯の如くして 造りたろ混合物に適當量の水を加ふれば容易に乳劑る 得ろものなり (Soc. Anon. La Trinidad, B. P. $279,026,13.6 .27$. Fr. 15. 10. 26) (市川)

\section{0. 乾溜、瓦斯及撚料}

メタノール合成 (A) 作業溫度か出來得万丈け等混 に保つ篇には次の注意え必要とす (1) $\mathrm{CO}$ と $\mathrm{H}_{2}$ の 割合各 1/5 とすへし然ろ時は過剩の $\mathrm{H}_{2}$ は溫度の上 昇方碍ぐ (2)觸媒の單位量につき單位時間の發生熱虎 引下ぐろ樣瓦斯の流速る加減する事 (3)觸媒嬄より熱 を速に逸散せしめ得万情裝置を作万事然万時は觸媒閒 の溫度差な $5^{\circ} \mathrm{C}$ 以內にしうぺし (B) 觸媒に關しては 次の如寻結果去示り $y$ (4) $\mathrm{Al}_{2} \mathrm{O}_{3} 、 \mathrm{SiO}_{2} 、 \mathrm{Mo}_{2} \mathrm{O}_{5}$ 、 $\mathrm{V}_{2} \mathrm{O}_{3}$ 等11 種の不活性酸化物方列舉せ $y$ (5) $\mathrm{Ce}_{2} \mathrm{O}_{3}$ $\mathrm{UO}_{2} 、 \mathrm{BeO} 、 \mathrm{ZrO}_{2}$ は $2 \%$ 以內 $\mathrm{MnO} 、 \mathrm{Cr}_{2} \mathrm{O}_{3} 、 \mathrm{ZnO}$ は 2〜17.5\%の收得あり（6）種々なろ方法によりて作 れろ銅觸媒の活性は 3〜35\%の開きむり㗂酸監溶液の 沈測法及び不安定なる有機監類の熱分解に出發さしも


ンか含みて不良溶融法に據りししのは最劣等なり（7）



C、 $\mathrm{CO}_{2} 、 \mathrm{CH}_{4}$ 名作万接觸能方も有して不適當なり （8）銅に亞鉛各促進劑として添加せるるのは收量 95\% に達す猶セリワム、マンガン等方促進劑とせるものを 80〜 90\%の收量あり但し此等は熱に對して甚だしく銃 敏にして例へば $450^{\circ}$ に於て 6 時間水素氣中に懪した 万に俄然活性減退し $\mathrm{Cu}-\mathrm{Zn}$ の)如きは 30\%以下に低 下さり（9)銅に促進劑として有効にしてHつ熱に堪け ろはベリリウムにして前述の加熱にも損ぜらろつ事な く依然 90\%以上の活性㤂保有包 (Etienne Andibert and André Raineau, Ind. Eng. Chem. 1928, 20, 1105)

(伀々末)（山田）

酸化及び影宸化の際に於ける石㞸の化照的變化 サ


$300^{\circ} \mathrm{C}$ までは酸素の吸收大にして能炭の水素及び炭 集含量及ひ發熱量龙減す $275^{\circ} \mathrm{C}$ にては 6.5\%、500$520^{\circ} \mathrm{C}$ にては $30.8 \% 、 600^{\circ} \mathrm{C}$ にては $38.3 \% 、 1000-$ $1020^{\circ} \mathrm{C}$ にては $47.8 \%$ の揮發分發生せり $275^{\circ} \mathrm{C}$ にて 90 分熱したろ骸岸は加熱能の $8037 \mathrm{Kcal}$ の發熱量よ り 7004 Kcal に減し酸素含量は 11\%ょり $15.78 \%$ に 塯加し脄素含量は $4 \%$ 、水素含量は $1.5 \%$ 方減ず 500-1000 $\mathrm{C}$ にては發然量再び $8000 \mathrm{Kcal}$ に增大し $\mathrm{C}: \mathrm{H}$ の比は $606^{\circ} \mathrm{C}$ まては徐々に夫ょりは急激に塯 し $1000^{\circ} \mathrm{C}$ にては胮素 $97 \%$ К过与 $225^{\circ} \mathrm{C}$ にて加熱時 间か 1/2-10時間の閒に變じて賽驗したるに常に 1-2\% の重量の增加か認めたり酸㨞分量は時問と共に塯し10 時間後には $9.93 \%$ よ $23.86 \%$ に遊せり炭素及び水 素含量、發熟量は時閌と共に減少し後者の減少は 10 時間後に $23.8 \%$ に迬せり同石炭のフュゼインに就ても 同樣の結果方得酸素含量は $5.48 \%$ ๖ 10 時閌後に 17.42\%に達せり (Oskar Künle, Brenn. Chem., 1928, 9, 295)

（兒 玉）

\section{アセチレン墢生用カーパイドの低溫生成に就て}

著者は比較的低溫に於てアセテレン發生用カーバイト か生成せんとし酸化バリウム原料として之かメタン 又は孷素と水素虑以て還元する事によりて其の目的る 赎し得ろ事な確めたり酸化バリウムは $800^{\circ} \mathrm{C}$ にて熔

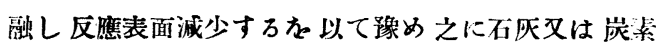


於て一定時間メタン又は水䋕氣中に一定時間加熱し得


元條件との關係か求めたり其の絬果に依ればカーバイ ト生成反應は $800^{\circ} \mathrm{C}$ 以上にて起り滋度の上昇と共に 塯大するも $1200-1306^{\circ} \mathrm{C}$ の間に其の最高限むり反㗹




万程良絬果方得11.つ反應溫度の降下か示才反應時間は 一般に短かく上記の如き賽驗にては 30 分にて充分な り(メタンか使用寸る場合には勿諭にれに應じてメタ ンの量も充分大なるる要す）酸化鐵又は酸化銅等の觸 媒は常些に於ては好結果艻與了万6減怔の場合には其 の效果著しからず著者の行ひたる實驗中最良の結果虑 得たろ場合は $\mathrm{BaO} 、 \mathrm{CaO} 、 \mathrm{Fe}_{2} \mathrm{O}_{3}$ の割合名 10:5:1 又は $\mathrm{CaO} 、 \mathrm{C} 、 \mathrm{Fe}_{2} \mathrm{O}_{3}$ の割合か 10:1:1 としメタン 方用的滅厚力水銀柱 $12-18 \mathrm{~mm}$ 溫度 $1150^{\circ} \mathrm{C}$ の場合に して此等の場合には理論、の $60 \%$ の收量㤂得ざり又 $\mathrm{BaO} 、 \mathrm{C} 、 \mathrm{Fe}_{2} \mathrm{O}_{3}$ の割合扂 20:7:2 とし水素占以て 盟力水銀朴 $12-14 \mathrm{~mm}$ 溫度 $1150^{\circ} \mathrm{C}$ にて理論上の $40 \%$ の收量杂得たり著者は佾之等生成カーバイドょり發生 すろ瓦斯中にはアセチレンの外に多少の水䇣の存在す ろ事加涊めたり而して其の水素の量は還元の際の各條


原因战掏求し之がパリウムカーバイト中に全ま万り金 屬バリウム、水化バリウム及サブカーバイドによるも のなろ事方確かめ之に關聯しバリウムカーバイド生 成の機掅㤂論及せり（F. Fischer F. Baugert, Brenn. Chem., 1928, 9, 328)

\section{（香坂）(角谷)}

亞硫酸瓦斯による含硫炭素の生成 萿者は裀望より


松枋、活性炭素等の一定量方 $300-500^{\circ} \mathrm{C}$ の㳢度に 加熱し之に亞硫酸瓦斯方通したる後生成物山に会まる


ろ事施認めたり面して其の含量は以前に漓滋に加熱せ られざるるの程大なり例へば純炭素（一酸化炭素より 生成せ万七の）の硫黄会量は約 $8 \%$ 、牛成䯓岸に於て は $32.6 \%$ 、濾紙に於ては $34.3 \%$ 、材樹に於ては 37.5 \%圭示すが如し而して此等に含まるつ硫黄はトルオー 儿等の溶媒にて抽出せらろ 事なく極めて安定に其の 炭素に絬合せら万著者は此の結合去以て化學的の結合 と斷ずろは速きも所謂吸着に非ざる事は磪賽なりと主 張せり (F. Fischer u. A. Pranschke, Brenn. Ch:m., 1928, 9, 361)

(㫘 坂)

\section{2. 染料、染法及染織}

グリニアール反筧に依るマラカイト・グリーン及び フェルル・フタレイン型化合物の㱔法 渚者笘は先つ バイヤー及びヴィリガーの方法にてフェニル・マグネ シウム・ブロマイドとミックラータトンより圤好なる 收量にてマラカイト・グリーンを得次にザックス及び
エールリッ七の方法にて $p \cdot$ ブム・ヂメチルア $=y$ ンよりグリニアール試藥か造りミックラーケトンに作 用せしめメチル・ヴァイオレットな製せり又 $p$ メフロ ム安息香酸よりグリニアール試藥の製法が武み良好な ろ結果な得ざりしも前記のケトンと作用して海綠色々 素右得該色素のエーテル溶液より重クロ么酸加里の媒 染る施したる羊毛各海綠色に染着し得たるか以て僅に クロム・グリーンの生成方確認しだ

$$
\begin{aligned}
& \begin{array}{l}
\left(\mathrm{CH}_{3}\right)_{2} \mathrm{NC}_{6} \mathrm{H}_{4} \\
\left(\mathrm{CH}_{3}\right)_{2} \mathrm{NC}_{6} \mathrm{H}_{4}
\end{array} \mathrm{CO}+\left(\mathrm{CH}_{3}\right)_{2} \mathrm{NC}_{6} \mathrm{H}_{4} \mathrm{MgBr} \\
& \rightarrow \quad \begin{array}{l}
\left(\mathrm{CH}_{3}\right)_{2} \mathrm{NC}_{6} \mathrm{H}_{4} \backslash \mathrm{CH}-\mathrm{OH} \\
\left.\left(\mathrm{CH}_{3}\right)_{2} \mathrm{NC}_{6} \mathrm{H}_{4}-\mathrm{C}-\mathrm{OH}\right)_{2} \mathrm{NC}_{6} \mathrm{H}_{4}
\end{array} \\
& \text { メキルヴァイオレット（カルビノール） } \\
& \left(\mathrm{CH}_{3}\right)_{2} \mathrm{NC}_{6} \mathrm{H}_{4} \\
& \left(\mathrm{CH}_{3}\right)_{2} \mathrm{NC}_{6} \mathrm{H}_{4} \\
& \mathrm{CO}+\mathrm{HOOCC}_{6} \mathrm{H}_{4} \mathrm{MgBr} \\
& \rightarrow \begin{array}{l}
\left(\mathrm{CH}_{3}\right) \mathrm{NC}_{6} \mathrm{H}_{4} \\
\mathrm{HOOCO}_{6} \mathrm{H}_{4} \backslash \mathrm{C}-\mathrm{OH} \\
\left(\mathrm{CH}_{3}\right)_{2} \mathrm{NC}_{6} \mathrm{H}_{4} / \\
\text { クロムグリーン(カルビノール) }
\end{array}
\end{aligned}
$$

倘 0 ・ベンゾイル安息香酸とフェニル・マグネシウム ブロマイドとよりフェノル・フタレイン型化合物の製 法は失敗に終りしが其生成物は恐らくヂベンゾィル。 ベンゾールにあらずしてフタロフェノンなろべしと推


Dull, J. Amer. Chem. Soc., 1928, 50, 3083)

(淺 岡)

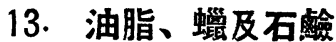

旰油の紫外光線吸收スペクトル (1) $250 \mu \mu$ ょ短 波長に對しては殆ど完全なる吸收行はれたり（2）290 $\mu \mu$ より長波辰の觀测は正磪龙期し難きも $320 \mu \mu$ 附近 にて可成强き吸收ある在知り得たり (3) $270 、 280 、 29$ $0 \mu \mu$ の近くに最大值方有する3 筬の吸收帶存在するは 肝油中の微量のエルゴステロール(ergosterol)に基く ものなり (Jay W. Woodrow, Phil. Mag., 1928, 944)

(住々木)

グリセリト及び異性理の生成（第一） Bellucei 及 び Manzetti 兩氏はグリセリン及びオンィン酸の重量 方炭酸瓦斯氣中及び減厴下に加熱しグッセリトの殆ど 理論量㤂得だり著者は瓦斯は触媒の作用虎念すしのな りや或は單に無作用物賀として用ひらろ〉ものなりャ 方知ら人が篇亞硫酸瓦斯、炭酸瓦斯、空素及ひ昤化水 素瓦斯か用ひオレイン酸及びグリセリンの當量か以て


る測定さり其の絬果は次の如し 
遊離酸百分率

\begin{tabular}{|c|c|c|c|c|c|}
\hline 時間 & $\begin{array}{c}15 \mathrm{~mm} \\
\text { 檿下 }\end{array}$ & 亞硫酸 & $\begin{array}{l}\text { 宸酸 } \\
\text { 斯 }\end{array}$ & 窒素 &  \\
\hline 0 & 100.0 & 100.0 & 100.0 & 100.0 & 100.0 \\
\hline $1 / 2$ & 48.0 & 55.9 & 49.6 & 53.8 & - \\
\hline 1 & 30.4 & 27.1 & 30.6 & 33.3 & - \\
\hline 2 & 20.2 & 16.1 & 19.3 & 18.6 & - \\
\hline 3 & 17.5 & 12.8 & 13.1 & 14.5 & - \\
\hline 4 & 14.5 & 9.9 & 10.6 & 12.2 & - \\
\hline 5 & 12.1 & 9.7 & 8.7 & 11.0 & -- \\
\hline \multirow[t]{2}{*}{6} & 11.7 & 9.4 & 7.4 & 10.6 & - \\
\hline & & 䍅化 & 霓 & & \\
\hline 2 & - & 166.3 & - & - & - \\
\hline 3 & 171.3 & 169.0 & 172.8 & 170.4 & - \\
\hline 4 & 176.2 & 173.6 & 177.3 & 179.8 & - \\
\hline 5 & 183.4 & 181.0 & 187.8 & 184.8 & - \\
\hline 6 & 187.9 & 190.1 & 190.5 & $\mathbf{1 8 8 . 8}$ & - \\
\hline
\end{tabular}

以上の賽驗より瓦斯の作用は主として機栈的なる事 方知れり但し亞硫酸瓦斯店用了万時は主としてシェラ イヂン正生じ色最も淡し宸酸瓦斯も淡色のグリセりド




分に作用し $200^{\circ} \mathrm{C}$ に於ては勿諭 $160^{\circ} \mathrm{C}$ に於て既に急 速な万宸化龙起す (T. L. Garnner, J. Soc. Chem. Ind., 1928, 47, 278T)

ベヘノール酸の合成 Mirchandani 及び Simousen 雨氏 $(J:$ Chem. Soc., 1927, 371) はインェルシ ン酸右酸化分解し該酸は $\Delta^{12.13}$ 及び $\Delta^{14.15} \mathrm{C}_{22}$ オレ フィン酸の混合物なりとせり著者等は之方确定せんが 䈍之等 2 種の酸の合成走企て先べべへノール酸方合成


於てはべへノール酸の合成法のみに就て記載せりその 方法としては次式に示寸如くナトリウムデシン (I) 及 び12 ブロムドデカン酸メチルェステル (II) 存縮合 せしめたり

$$
\begin{gathered}
\mathrm{C}_{8} \mathrm{H}_{17} \cdot \mathrm{C} \equiv \mathrm{CNa}+\mathrm{CH}_{2} \mathrm{~B}_{2} \cdot\left(\mathrm{CH}_{2}\right)_{11} \cdot \mathrm{CO}_{6} \mathrm{CH}_{3} \rightarrow \\
(\mathrm{I}) \\
\mathrm{CH}_{3} \cdot\left(\mathrm{CH}_{2}\right)_{7} \cdot \mathrm{C} \equiv \mathrm{C} \cdot\left(\mathrm{CH}_{2}\right)_{11} \cdot \mathrm{CO}_{2} \mathrm{CH}_{3} \\
\text { ベーノール酸 }
\end{gathered}
$$




更にメテルェステル（沸點 $165^{\circ} \mathrm{C} / 10 \mathrm{~mm}$ ) と篇し之に




$1 \pi{ }^{\circ} \mathrm{C} / 10 \mathrm{~mm}$ ) となし更に Grün 及び Wirth 氏法
(Ber., 1922，55, 2215）に依りモノメテルェステル （融點 $51^{\circ} \mathrm{C}$ ) に變じ（無水アルコール中にて）ナトリ ウム龙以て還元し水酸化酸（融點 78-79 $\mathrm{C}$ ) 在得けり 之方悬化水素にて處理し12 ブロモ・ドデカン酸メチ ルェステル（融點約 $50^{\circ} \mathrm{C}$ ) と篇せり次にI品得るに は液體アムモニアやにナトリムウアミド啋垂しアセ チレン杂通じえに沃化オクチル $\left(\mathrm{C}_{8} \mathrm{H}_{17} \mathrm{I}\right)$ 吉作用せ しめ更に之名水㲈氣中にてナトリウムと反雔せしめて I 死製したり以上に得たる I なキシロール中に於て II と反應せしめ後キシロール及び過剩のデシンな虚




結晶せしめたるに碳點 $57^{\circ} \mathrm{C}$ の美麗なる釗狀結晶か得 ホり 之ねェルシン酸より得たるべへノール酸と混瀜し たるに 56.8- $57^{\circ} \mathrm{C}$ にて熔融し其のべへノール酸なる 事龙碓めたり（R. Bhattacharya，S. R. Saletore and J. L. Simonsen, J. Chem, Soc., 1928, 26-78)

(紀)

\section{Philippine Lumbang oil より得る $\boldsymbol{\alpha - リ ノ ー ~}$} ル酸六臭化物のエステル 著者等は资に示すェステル


檢したり

$\begin{array}{cc} & \text { 融 } \\ \text { 點 } \\ \text { 正プロピルェステル } & 144-146^{\circ} \mathrm{C} \\ \text { イソプロピルェステル } & 141-143^{\circ} \mathrm{C} \\ \text { イソブチルェステル } & 136-138^{\circ} \mathrm{C} \\ \text { アミルェステル } & 133-135^{\circ} \mathrm{C}\end{array}$

(M. L. A. Vicente and A. P. West, Brit. C. A., $1928,1115)$

魚油より新脂助酸 藷者は Dorosoma nasus, Bloch の油より新脂肪酸龙分新せり元素分析:炭素 74.53、 75.25、水䇣 12.66、12.76 Kて $\mathrm{C}_{17} \mathrm{H}_{34} \mathrm{O}_{2}$ なる酸に 相當す其の融點 $55^{\circ} \mathrm{C}$ 、中和袋 207.39 (理諭數 207.7 ) バリウム会量 $20.14 \%$ (理諭數 20.29)、鉛監の鉛合 有量 $27.14 \%$ (27.78)、此の酸は未だ嘗て動物油より 分離せられたる事無子ものなり (H. Morcelet, Compt. rend., 1928, 187, 145)

\section{4. 芳香油及香料}

$\alpha-\beta$-ピネンの存在に就て 從來精油中に检出せら れたる $\beta$ - ピネンは左旋光性の物なりき ハルゼ氏等 (Halse, Dedichen, Ber., 1917, 50,623) はスルフフ ートテル ッンチン (Suliatterpentin Oel) 油に $\alpha$ - $\beta$ ピネンむりと信じアスカン (Aschan, C. 1919, II. 
284)は同樣の油より二環性テルペンる得たるるこトロ ソクロリト各生じかつ過マンガン酒加薣液にて酸化す る時オキシ酸占尘ざず著者はアフガニスタン地方にの みあろ繖形科植物 Ferula Badra-Kema (F. galbaniflua）の熟せ万果實后蒸氣蒸溜にて $2.35 \%$ 收量にて精 油名得たり之石石油エーテル次に酒精にて抽出すれば


香氣めり $d_{20}^{20} 0.8736 、 n^{20} 1.4765 \alpha_{1}+16.16^{\circ}$ 、酸價 1.2、ェステル價 6.65、醋化後ェステル偵 $31.78 \%$ にて 成分は $\alpha-\beta$-Pinen 30\%[沸點 162-163、 $d_{20}^{20} 0.8662$ 、 $\alpha_{D}+20.75 、 n^{20} 1.4745$ (不純なり $\alpha$-ピネンおり)、


$[\alpha]_{D}-18.35^{\circ}$ 、其七ミカルバゾーン融默 187-188 $] d$ 、 l一更 $d-\alpha$-ピネン 40\%[ニトロソクロリト融點100101、ピノン酸セミカルバゾーン融點 203-204ํㄱ、dりモネン $1.5 \%$ [ヂベンテンヂヒッ゙ロクロリト䏇點 $50^{\circ} 、$ 他に磼整なし、一程のアルコール 3\%、ケトン $1 \%$ なりと外に融點 114-116 の酸走得たり (B. N. Rutowski, I. W. Winogradowa, J. pr. Chem. 1928, 120, 41) (平 尼)

ピペロナールにチアゾメタンの作用 ピペロナール $10 \mathrm{~g}$ Кメチルアルコールの存在の下にずアジメタンの エーテル溶液施作用寸ればピペロニルアセトン（沸黙


セチルビペロン(沸點 145-147\%/9mm、融點 87-88.5 、 七ミカルバゾン融點 $\left.239-240^{\circ} 、 0.7 \mathrm{~g}\right)$ 恐らく $\alpha-3: 4-$ メチレンヂオキシフェ:ニルプロパン $-\alpha: r-$ オキシド $\mathrm{C}_{10} \mathrm{H}_{10} \mathrm{O}_{3}$ (沸點 140-143\%/9m $3 \mathrm{~g}$ 、ケトン性なら ず）な生ず然るにメーテル溶液のみにて作用すれば主 としてアセテルビペロン教じ $\mathrm{C}_{10} \mathrm{H}_{10} \mathrm{O}_{33}$ の年成は 僅少なり (E. Mosettig, Ber., 1928, 61, 1391)

(本 尼)

新香料及其用途（I）アミルオキシインオイら゙ノー ル殆ど哭色の液體なり沸點 $150 〜 156^{\circ} / 3 \mathrm{~mm}$ 、比而 1.0297 1.0351、 $n_{D}^{20}$ 1.5287-1.5308、70\%淮精6 行に 溶解寸甚決快香あ万メチルイソォイゲノールに似又强 きカカオ及ら゙ァニー二㥆の調子あり故に丁子及モード


料として問題になり得万如しガルテンネルケ (gartenNelke）の調合例がげたり（II）フェニルニヂルザリ シラート 娜默䄪 $180^{\circ} / 3 \mathrm{~mm}$ 常㳶にて固整なるも甚だ 容易に液化し否独は言ひ表はし灘きも濃度に依り葆し くバラ、丁子の如く又造に七ヤシンス思けしむ故に 花精油、ファンタシシー香料の偍秀なる基楚となるフェ


ばよく之る。代用し得七ヤシンス其他數種の調合例かお。 げたり（H. Janistym, Deıt. Parf. Zlg., 1928, 14, 404)

(平 尾)

精油抽出劑としての液骾岸酸 從來精油は有機溶劑 油脂、水蒸氣の如きにて抽出したろが之等には種々の 缺點あり例一ば有機溶劑使用の場合には之れる完全に 精油より除去し得ず又香氣の害せらるくことあり然る に此の液體炭酸志用了万時は精油岁香物質の抽出火理 想的にして定量的收量にて得られ抽出後は自然に具完 全に炭酸蒸發す而して本法に低れば常淴にて未だ嘗て 得られざりし奵收量にて完全に純精に然も變化無くし て得らるべしと特に花、種實、根、例へば丁子、キャ ラウェイ、イリス等に䭃用し得操作中に蒸發する炭酸 は再び液化して循環用ひ得例一ば粉粹せ万丁子 $150 \mathrm{~g}$


酸溶液な受器に流し蒸發せしもれば後に最も良質の透 明翼金色油 $18 \mathrm{~g}$ 龙得抽出殘渣は最早精油方有せず (Vianova, G. m. b. H. f. Chem. Ind. Berlin, No. 292982. Brit. Pat. Spec.; P. E. O. R., 1928, 19, 346)

(平 尾)

チモール及メントール製造法の改艮 英國特阡 No. 15992/1927 及び 28803/1927 に依つてメタクレン゙ール 及びアセトンょり種々なる條件に作つて種々なる縮合 生成物虎得ら万此等は熱處理に於て 3-メチルー6-イy プロピレンーフェノールな分離す No. 15993/1927 は茹 に得られたらフェノール硬にチモール乃至はォント ールとなす以上の場合にメチルーイソプロ ピレンー フェノールは加熱に於て一部分重合し從つて製造の困 難各大ならしも此處に記載せんとするは此の重合品避 けんとするところの追加特詐なりとす先づ No. 15594 /1927 に依りメタクレゾール皮アセトンの繀合生成物 のアシル化合體长作万此等のアシル化合體はフォーミ


如し No. 15992/1927 に依つてメタクレソール及アた トンより縮合生成物良得これ吕モノーアセチル化合體 となし次にこれを蒸溜釜中にて的 $300-320^{\circ} \mathrm{C}$ に加熱 すこいに得らろいメテルーイリプロピレンーフェノー ルーアセテート及赵びメチルーイップロピレンーフェ， ールの混合物か蒸溜すこつに得ら万い混合物はニッケ ル䪅媒の存在にてチモール及びチモールア七テートと に水督化㤂なす（No. 15993/1927）アセテートの混合 物は鋊化によりチモールとなす（Perf. Essent. Oil Rec., 1928, 19, 387)

(稲本) 
チモール笠造方法 英國特竍明細書 No. 293753 に 依れば霄加厤力及千モール分解溫度以下の溫度に於て メタクレゾールとプロピレンとの反應に俵つてチモー ルね得らろと云ふ一例として示すところに依ればメタ


れに類似の加烋装置中に 70 時間粎 20-40 氣厴にて $350^{\circ} \mathrm{C}$ にプロピレン $350 l$ と共に加熱しその反應混合 物より分别蒸溜に依つてチモールね單離し得らろこれ な゚゙ンゼンる用ひて結晶せしも以上の場合に於けろ溫 度は更に適當なるもの龙めらろぺきものにして概し て約 $300^{\circ} \mathrm{C}$ とせられ他の條件にも依るとは云へチモー ルの分解溫度より約 $50^{\circ} \mathrm{C}$ 以下となり斯くの如くチモ ールがメタクレゾールにプロピレンの作用にて得らろ 、は警くべきことにしてチモールが五酸化䊅の存在に 於てメタクレゾールとプロピレンとに分解すると云ふ 一例を見ても全く意外なりとす本法に從へばメタクレ ゾールは大部分チモールに置換せらろ (Perf. Essent. Oil. Rec., 1928, 19, 387)

(岡 本)

苏子油の香洏之搆造 (第三報) ハロゲン、メチル、 ニトロ基の含西影響 芥子油構造山に於けろメチル基<smiles>C1CCCC1</smiles>

(34)



(35)



(36)



(37)


辛辣性即眞正芥子油香氣の程度に依り（34）文 (36)、 （35）及（37）の2 對に别几前者は芥子油否埭者しく




於て此等 4 個の化合體洂亦アニス樣甭氣店保有しその パラの位置にクロ口基名有す万(36) 及（37）に於て その著しき死見る之等より結俩し得るところはメ夕㩆 換は芥子油否氣方面してパラ置換はアニス樣香氣を头 々誘出することにして及クロロ基はメチル基より香氣 浱動數る變ずっ力量大なり例へば（35）に於てはパラ


が殆んど的倒し（36）に於てその遊方示すが如し次に


クロロ基がメチル基より香氣支配の力大なるる磪かめ


實驗に用ひられたるは 2ーメチルー5ーメチル、2一ク ロロー5ーメチル、2ーメチルー5クロロ、2一クロロー 5ークロロの 4 種のフェニール芥子油誘導體なり佾ほ



驗せり






ざ万旨記載せり (G. Malcolm Dyson, Peif. Essent. Oil Rec., 1928, 19, 171)

(閌本)

\section{5. 顏料、塗料及樹脂}

\section{亞麻仁油塗料の酸化及び風化に對する新しき研究}


酸㨞、光線、濕氣、菌の作用上り研究过り老化の主因 たっ酸化る二段に别ちて考ふっ時は第一段に於ては亞 欴仁油分子の二重結合に酸素が結合し酸化が行はれ皮 膜龙生成し再量の塯加店來し第二段に於一は少それ以 上の酸化により物啠的に分解し所謂老化长赸すものに してこれは第一の酸化に比し総かに起り又酸化生成物 た失ふためにその重量龙減ぜり酸化により生じたる過 酸化物は有力な万酸化劑として作用し酸化生成物とし


プロピオン酸、アゼライン酸等の䯩級の酸も檢出しナ:


相邀おり著者の测定によろ時泣酸化により失子炭素の 量は14日後には 4\%56 日後には $8 \%$ はき光線の作




鉛白は最し作用子受け易く酸化チタンはその反對なる


て試料方飽和乘中及び水中にて試驗したるに皮膜は膨


せり少皟料の影響方检したろに釉白、酸化チタン、ブ ランフィクス、不英等は大な万影響はなく酸化亞鉛は 渚しく膨脹せしむろことを見たり菌の作用も皮膜の老


度にて培垗す万时は繁殖甚だしく僅 14 日にして全然 皮膜わ崩靠さしむろことあり菌の慗殖は酸化亞鉛によ り幾分好げらろつも鉛白、鉛丹、酸化チタン、リトホ ン管は效果少し (Dr., D'Ans, Z a angew. Chem., 1928, 41, 1193)

(山田) 


\section{6. 護謨}


によ万硫化に耐ふれ共多くの孟基性及㨁接木綿染料は 概して不良なり硫化染料は丈夫なれども酸性染料に比 して色澤讶えず.H.弱き怨めり台ブルカホーア染料は興 味深き性質方有寸需氣沈積にも用ひ得られ强寻被覆力 と光線・酸アルカリに强き性賀方有寸 (W. E. Sanderson, India Rubber J., 1928, 76, 325) (石 黑)

再製護謨製造の要領 製造法の實際につき詳述せり (P. S. Shoaff, India Rubber J. 1928, 76, 284;
Ind. and Eng. Chem., 20, 2)

（石 黑）

载培護謨の可塑度の差異 護謨製造家は愿々可望度 の異万護謨か見万が更に均一な品か供給し得るゃ否や な磪かもろためこの差異の原因㤂研究せり

（1）試驗法 原料、煉護謨及び硫黃混合後の可塑度々 測定せりパラレルプレートプラストメーターにて $D_{30}$ 走測定し煉護謨はセイロン護謨研究所式押出器 各以て排出量 $E_{v}$ 定算出せり $D_{30} \cdot \sqrt[4]{E_{v}}=K$ （2）差異の籁圍 セイロンの各地より得たる 39 種の スモークシート及びクレップに就きて試驗し向多少の ハララヤ S. L. R. Кついても第三表に付記せり

\begin{tabular}{|c|c|c|c|c|c|c|c|c|c|c|c|c|c|c|c|c|}
\hline \multirow{3}{*}{ 護讙 秚 } & \multirow{3}{*}{$\begin{array}{l}\text { 試 } \\
\text { 料 } \\
\text { 数 }\end{array}$} & \multirow{2}{*}{\multicolumn{3}{|c|}{$\begin{array}{c}\text { 原料濩謨 } \\
D_{30}\end{array}$}} & \multicolumn{5}{|c|}{ 煉 萑 謨 } & & \multicolumn{6}{|c|}{ 硫识混合謢謨 } \\
\hline & & & & & \multicolumn{3}{|c|}{$\widetilde{D_{30}}$} & \multicolumn{3}{|c|}{$\underline{E}_{v}$} & \multicolumn{3}{|c|}{$\widetilde{D_{30}}$} & \multicolumn{3}{|c|}{$\overline{E_{v}}$} \\
\hline & & $\begin{array}{l}\text { 平 } \\
\text { 均 }\end{array}$ & 最 & $\begin{array}{l}\text { 最 } \\
\text { 小 }\end{array}$ & $\begin{array}{l}\text { 平 } \\
\text { 均 }\end{array}$ & 最 & $\begin{array}{l}\text { 最 } \\
\text { 小 }\end{array}$ & 平 & 最 & $\begin{array}{l}\text { 最 } \\
\text { 小 }\end{array}$ & $\begin{array}{l}\text { 平 } \\
\text { 均 }\end{array}$ & 最 & $\begin{array}{l}\text { 最 } \\
\text { 小 }\end{array}$ & $\begin{array}{l}\text { 平 } \\
\text { 均 }\end{array}$ & 最 & $\begin{array}{l}\text { 最 } \\
\text { 小 }\end{array}$ \\
\hline スモークシート & 12 & 169 & 192 & 154 & 79 & 91 & 67 & 8.5 & 14.6 & 4.9 & 67 & 79 & 57 & 14.8 & 26.8 & 8.8 \\
\hline 氣乾クレップ & 17 & 177 & 190 & 163 & 83 & 90 & 75 & 7.5 & 11.4 & 4.9 & 91 & 79 & 62 & 12.4 & 18.7 & 9.0 \\
\hline 機憼クレップ & 1' & 164 & 182 & 144 & 80 & 88 & 70 & 9.4 & 17.4 & 6.6 & 69 & 76 & 59 & 15.0 & 26.4 & 11.7 \\
\hline  & 6 & 175 & 192 & 164 & 87 & 95 & 83 & 5.1 & 7.1 & 3.0 & 74 & 82 & 69 & 8.6 & 11.0 & 5.6 \\
\hline - & 4 & 166 & 200 & 152 & 77 & 87 & 72 & 12.6 & 15.8 & 5.3 & 73 & 77 & 68 & 14.9 & 19.0 & 6.8 \\
\hline
\end{tabular}

これによろと各試料の最大、最小间の美異の方が各種 類の平均値の差異よりはろかに大なり即可塑度の差は クレップやンートの製造法にょろに非ずして各試料に 依存す

（3）差異の原因 可憼度と硫化の閌に江著大の關係存 す硫化早きものは硬く然らざるるの沬之に反すこの可


淡度、熛䙳の具合熟成の度合によるるのなることる明 かにせり ( F. L. Elliott, India Rubber J., 1928, 76, 212)

(不 黑)




性質形狀につ基數學的に解铳せり (R. Ariano, India Rubbor $J$., 1928, 76, 208)

種々のカーボンブラックを配合せるゴムの䟦隇試驗 棈々の種数のカーポンブラックか含むラパーストック に就き一定の仕事死なし終へたろ後の磨滅減量かウィ リアムス磨隇試驗機によりて比較測定せり試料の大さ が $0.45 \mathrm{~mm}$ まで塯大寸ろに從つて磨滅減量も亦塯加 し其後は著しく急速に娍少寸万后發見せり此等の結果


々のカーポンブラックか命有する未老化ストックの整 減隇量が之等のストックが゙ーアオーブンウにて老化 したるものの磨減娍量に對する比秦は一定ならず故に

或種のカーボンブラックは他の種類のものょりゴムの


(W. B. Plummer and D. J. Beaver, India $R u$ bber World, 1928, Oct. 1)

（大 木）

カウチュータより造られれる熱可檠性ガッタパーチ


並に同問題の系統的論述 ガッタパーチャ、バラタ及び えラック栐の熱可塑性物質にカウチュークな變化せし むろ興味あろ問題に就いて過般フィッシャ一氏（Harry L. Fisher）が同問題に關寸万實驗と諭述と死米 國グドリッチ 會社發行の小冊子に公表したるに對し著 者は此の方面の研究が今日に始まれるものに非ざろか。 逨へて 1910 年に於け万ハリス氏 (Harries) の研究 より逐次之れ虚史的に諭迌して著者自らの此に對寸 ろ功縜も紹介してフィッシャー氏の研究の意義と其の範


カウチューク杂以て固體の滥處理せろ事、强硫酸以外 にサルフォン酸、サルフォクロライド等の有機性慗品 龙使用したろ事及ラテッキスを使用せる事等の䜅點に 就ての技術上の原理に進みて推論し其の伹先權の那㭡 におろや后磪定せり

最後に荞者は其の綜括に於てフィッシャー氏に低りて 有機性のサルフォン酸及サルフォクロライド等の作用 に依りて固體のカウチューク放加熱しつ、濃厚なる硫 
酸え作用せしめたる如き狀態の下に生成されたろガッ タパーチャ並にセラック樣物質は其の原理に於きて數 年前著者に侤りて發見されたら强硫酸の作用のみに依 りて溶液狀態にてアフリカ種のカウチュークに依ろ篎 化產物と完く同一物なる事店示し>ィッシャ一氏のサル フォカウチュークに對する發見の先取權は獨逸國の關 係事項なる事方力誈して結論せり

更に著者は上記サルフォカウチュークと其の化學的 構造に於きて類似せるサイクロカウチュークの一群の 全體叴サルフォサイクロカウチューク（Sulpho-cycloCaoutchouc)、サーモサイクロカウチューク (Thermocyclo-Caoutchouc)、フネトサイクロカウチューク (Photo-cyclo-Caoutchouc) コンタクトボリマーカウ チューク(Contact-polymer-Caoutchouc)の 4 種に分 類して其の發見者と發胃年月、製造方法、物理的及び 化學的に見たる性質並に想像さ万〉其の化學構造等の 項目に就きて詳細に表示し各變成物がかる總ての點


† (Dr. F. Kirchhof, Kautschuk, 1928, 4, 142)

(㵞 谷)

\section{7. 紙、絽維及セルロイド}

諸種の人造絆絲の蛅鞉性乙伸張度 種々の人絹の粘




驗せし絲の數も僅少なり著者等の赛驗に於てはヴィス


維素絹の種々の太さの絲の多くに就寻試昫し.H.つ $72^{\circ}$ F の恒溫度にて異れる濕度にて测定せり之れが湘定に は Baer Single Thread Testing Machine 施伐用せ y濕潤時の絲の粘勒性、伸張度测定には醋酸繊維素絹 の場合 15 分間少くとも水中に浸すを装するも他の人 絹は 1-2 分間にて充分なり各測定前 30 分問别々の 恒濕室中に保つ斯くして絲龙試欲せしに何れの人絹の 場合に於ても粘鞄性は濕度の大な万程少く伸張度は大 なり次に濕度吉種々に變化せしめてその際の粘勒性方 测定し燳度、粘制性龙夫々横座標、絽座標に取りしに 殆んぞ直線的の曲線态得たり之れにょりて任意の濕度 の際の粘勒性吉知り得晌著者は $66 \%$ 濕度の際の蛅勒 性と任意の濕度のそれとの比各 Factor と稱し任意の 濕度に對す万 Factor 右求め之れ等にょり Humidity Correcting Curve 死作乞りから万結果よりして次の 結論㤂得たり（1）乾濕の如可か問はずヴィスコース 絹の補正されし䉼吻性は細番手は太番手ょりも大なり


コースの伸張度の牛分なるる粘勒性は幾分大なり（3） 醋酸瀻維素絹は乾燥狀態に於ては粘鞄性はヴィスコー スより少し小なっる濕潤狀態に於てはヴィスコースと


はヴィスコース綃より幾分大なり（4）シャールドン ネ絹は銅アムモニア絹と殆んど等し（P．E．King， A. I. C., F. T. I. and E. N. Johnson, M. Sc., Dyers and Col., 1928, 346)

（管 原）

酸化維維素檢出に對する新試䒚 酸化瀻維素檢出に 最も羓通に使用さろはメチレンブリューなり之れに依


毒色と制然と區别す万能汶ず又酸化繊維素の還元力に 依万種々の試摹が提唱さろハリンン氏 (Harrison)は (Soc. of Dyers and Colourists, 1912, 28, 361) 銀

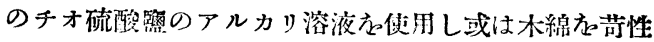
曹洼液中にてフラバンスレンの墅濁にてパッド及ひ蒸


の暗青色のロイコ化合體に㽡元されて固定さろ之れね 洗滌せばフラバンスレンの過剩注除去されロイコ化合 體は再び酒化され酸化纎維素方黄色に染む然れども着


件は容易に還元されH.つ無色な万物筫にして酸化纎維 素は漂く着色す万も還元さざ部分は染まらざ万后要 寸寫真師はフェリシアンの第二鐵覧の形にて長らくか


加里、フェリシアン加里の混合物にて處理せは迅速に 㫪色となろ然れども此の謂色液は酸化織維素に反應さ ず然れども同樣なる性筫る有し滿足なる結果る與ふ万 新試驗藥は次の如し (A) 硫酸第二鐵 $20 \mathrm{~g}$ 硫 酸アンモニア 25g (B) フェリシアン加里 $33 \mathrm{~g}$

（A）（B）在各冷水にて浴解して $100 \mathrm{cc}$ とし各溶液 5


1 分間其液に浸洞し後取り出し最初は稀硫酸次に水に




く白からず米徆木線は紋分フェリシアンの第二鐵覧に 對し還元性龙呈才 (W. F. A. Ermen, M. A., S s c . of Dyers and Colourists, 1928, Xliv. 10, 303)

\section{(㕮 原)}

\section{キシランて對するアルカリ及び二硫化㞸素の作用}

（繶）著者答汢前號に於てキシランのアルカリ化合體 アルカリ・キシランに對する二硫化炭素の作用及びア




就き報告せしも本號にはキシランの決定法並びにキシ ランの精製よりキシラン、ヴィスコースの製选迄の方 法及び實驗絬果に就き詳逝せりキシラン含量の测定は

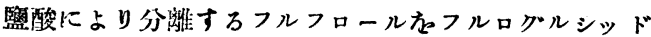
として部算するトレンス氏 (Tollens) 等の方法及び全 有機物古定量的に酸化して崖酸无澌とす万方法あり發 生せろ炭酸瓦斯かメッシングル氏 (Messinger) は加里 装置にて取るもべル、インヌス雨氏 (Berl ŭ Innes) はクロム酸及び燐酸龙使用して酸化し炭酸五斯はルン ゲ、リットナー雨氏 (Rittner ŭ Lunge) の方法にて 瓦斯分析的に测定せり然んども此等は充分に精密なら ず人絹及びパルプ工業に於てはブロンネル氏・(Bronnert）の方法によ万即ち重クロム酸加里と硫酸にて酸


してフェロアムモンズルファート及びシアン化加里の


に必要なる酸㨞量より有㙨物の量㤂补算し炭素量名求 めたり炭酸瓦斯の決定は落酸際にては非常に良子值各 與ふ万も游定法は埌好ならず故に落者は酸の濃度、登 獬の時間、重クロム陵加里の過剩及び酸化行程中に於 けろ水銀の影製等の如き種々の因子の影響等に就いて

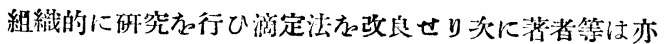
イザー及びブラーデン雨氏により考案されザルコスキ 一片により改良されし为法にて作られしキシランれ原 料としてアルカリキシランの生成並びにアルカリキシ




sch, Cellulosechemie, 1928, 9, 109) (斧 原)

絩維素問題に就て 纎維のレントゲン圖より㵶維素 はセロビオースより成立すとの著は次の 2 つの假定よ り鎳かれしものなり（1）㵶維素よりセロビオースが 60\%の收量にて得らろいこと（2）セロビオースが出來 万條件ではグルコースはセロビオースとならず著者は 此說に反し（1）に對しては瀻維素るアセトリーゼする 際に先づ Hess 氏篮のビオース無水物が生じ此物が更 に50\%の收量にて七ロビオースとなる即繊維素よりセ ロビオースの生成とセロビオースよりグルコースの生 成との機構は全く異なるものなりと主張す（2）に對し てはアセトリーゼの條件にてグルコースよりセロビオ 一スは生成せざる事實は七口ビオースが瀻維素中に存 在す万登據とならず織維素の構造因子に關寸ろレント ・ゲン圖の研究は多けれぞも構造化學的に既知の宸水化 物のレントゲン圖の研究がなく篇に繊維素とがルコー ス、セロビオース或は Hess のビオース無水物との問
にレントゲン圖に於て如何なろ相異が存在するやね比 較すること得ず著者は六醋酸化ビオーザンとクロロ フォルム溶液より再沈溉せる三醋酸化纎維素とはレン トゲン圖はよく一致しヌビオーザン圖と七ドラート瀻 維素圖とは一致し 6-メチル化ビオーザン圖と3-メチ 儿繊維素圖とは一致すかく圖の一致よりその單位細胞 中の排列の近似せることる考ふっ方得著者は Meyer 及 Mark 或は Sponsler 及 Dore Freudenberg茲 に Hawarth 氏等の纎維素の構造に關する說には反對 するものなりグルュース、セロビオースその他の糖類 のデバイ・シェーラー圖はその主干渉環の同一週期が 總てよく一致しその同一週期は綱狀面の距漓倠に相當す ろものにて平均 $4.5 \AA$ なりこの長さは之等の糖中にあ 万 Hydro-Pyranring の長さ及副によく一致す而し て之と同樣の同一週期が七ドロ纎維素及ビオーザンに も見出さろ之より明なる如く繊維素は既 知の糖類同 樣 Hydro-Pyranring の形にて排列さろ Octacetylecllobiose は醋酸化ビオーザン及醋酸緎維素と異なる 主干啮環か與へ5.3 A なり Sponster 及 Dore 或は Meyer及 Markによればセロビオース團にて連なりそ の同一遇期は $10.3 \AA$ ミしてかつ万排列方す万時は醋 酸化店行へは醋酸基の入万場合は過狭なり（K. Hess und C. Trogus, Ber., 1928, 61, 1982）（中 島）

\section{9. 醱醉}


試驗にはピルゼナー秉訝艻用る三仕込法によりて麥汁








法(涴度5.6- $9^{\circ} \mathrm{C}$ 、日數 9-10 日間) の 3 方法在行小各 試驗中の $\mathrm{pH}$ 價、醴醭度、酸酵の狀態等に就て記述


味其他の品質に就き論述せり其結果によれば正常又は


の場合には其香、味不良なり㛄するに醴醏は低猡長時 間方要して行はしむへく溫度 7-8 $\mathrm{C}$ 以上には上昇さ しもべからず (Horch u. Schulteis, Woch, Brau., 1928, 45, 394)

(騌) 羁)

醇母細胞成分及特に燃酸が酸醇に及す影響 本編は


合にも適用し得酥母成分として先づ絰素化合物は一般 に酸酵力强き酵母に於ては其の含量大なれど必ずしる 
此量のみか以て醴醉力の大小る決定すること能はず細 胞核の成分×クンイン酸は關係なきが如しヴホルチン の量は良好酵母にありては醴醉中に增加し不良醉母に おりては漸次消失す又燐酸に富も酵母は常に多量のヴ


な以てヴホルチンの增加は良好䤉母の原因と看做し得 アミ>酸其他蛋白分解中間產物は醗醉力と關係無 き 其量 10\%方越ゆるときは醉母の分解によつて生じた ろるのと考へられ該酥母の保存力不良なること虎表は


リコゲン少量なり咨に鑛物成分中最も重要なるは燐酸


麥粉中の燐酸監含量も大な万役目方有す此他酽母の カリウム含量の高きものは常に大なる 醇酵力な示す (Baetslé, Ann. Brass. Dist., 1928, 24; Woch. Brau., 1928, 45, 470)


醱醋によつて生ずろ宸酸瓦斯には硫化水素㤂混在する ものならが其量は演造の際の榙種條件に依つて異りこ れる定量することは最好なる娄酒后製造す万上に於て 甚げ參考となるものなり其の定量法として著者はこれ な硝酸鉛溶液に吸收せしめて硫化鉛となし.Oehme 氏 法により比瑟せり實驗結果店綜合寸れば次の如し硫化




酵母使用量注此祭關係せず酳母の自家消化によって著 量の硫化水素卡生ず醇造用水中硫酸監特に硫酸カルシ

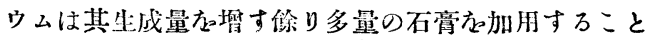
は避くへし麥汁山に存在す万合硫黄空素物は $\mathrm{H}_{2} \mathrm{~S}$ 生 成の最大の源となり原大娄又は麥第によつて其量を異 にす麥汁名ホップと照沸すれば $\mathrm{H}_{2} \mathrm{~S}$ 生成量走約 $50 \%$ 減少せしもトループの塯加も $\mathrm{H}_{2} \mathrm{~S}$ 生成量杂塯す波


にす麥汁に亞硫酸虏加へ万ときは一部は麥酒膠質物と 絬合して液中に殘溜し又生成瓦斯中の $\mathrm{H}_{2} \mathrm{~S}$ 量をも喍


行はざるものに比し $\mathrm{H}_{2} \mathrm{~S}$ 生成量多し又整酰液の $\mathrm{pH}$ 價も關係ありてアムモニアによつて麥汁の $\mathrm{pH}$ 價虎 上昇せしもるときは $\mathrm{H}_{2} \mathrm{~S}$ 生成量㤂減じ藇酸によつて 低下せしも万ときは其坐成量圶增寸酸酰溫度の上昇は $\mathrm{H}_{2} \mathrm{~S}$ 生成量各㣜し之れ龙低下寸万ときは $\mathrm{H}_{2} \mathrm{~S}$ 生成 方減少せしめ滋味及び泡持か后好ならしも以上の結果 は實驗室にて得たるるのなるが此の他工場に於て主及



(Wanderscheck, Woch. Brau., 1928, 45, 441, 463)

（路 澤）

或種麥酒成分による葰酸の吸着に就て 麥酒中に存 在す万萑酸は多く麥牙に由來し小部分はホップに由來 す此のものは醴酵の際に生成せず寧ろ其間に減少す麥




正電荷方有す万蛋白粒子に吸湴され次で溶存せるカル シウムと結合して葆酸石灰となり立に生成せし小結晶


に可視大の粒子となつて沈降するに至つて止屯葆酸石


中其の溶解度は減少す淡色麥酒にありては此の減少は

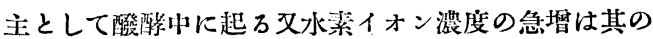

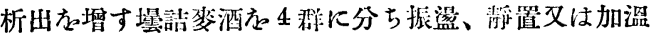
して1ヶ月 $1^{\circ} \mathrm{C}$ に眝藏せし後畧酸に就き檢せしに振


して蛋白筫物の沈降と葆酸石死絬唱との間には關係お






万蓚酸の吸䈐に基くなり（J. Raux, Brass. Malt., 1928, 18, 59; Woch. Brall., 1928, 45, 407)

(暍 攞)

\section{0. 製革及膠類}

屈折計に依る翏夜の震度測定 膠浓の浀度老簡單迅 速月磪赛に知万事は賿製造業者にとりて远げ車裂なる 事なり比重の測定により激度方知万事は時間と熟練な 要し其の徏磪度は 士0.5\%なりこれに反し屈折計艻用 ふろ時は液の溫度、透明度等により多少差異あれども $\pm 0.10 \%$ 以内の精磪度に於て行子事放得䔰研究に於て は Zeiss dipping refractometer老用め度く一致せる 值か得けり其の計算式炎の如し

$$
n-n_{1}=a \times c
$$

$n \cdots$ 液の屈折率

$n_{1} \cdots$ 溶劑の屈折率（この場合水にして $26^{\circ} \mathrm{C} に$ て 1.33298)

$c \cdots$. 波小の膠の百分率

$a \cdots$ 膯又はゼラチンり比屈折率（み均 0.00161） (A. G. Hart, Ind. Eng. Chem., 1928, 20, 870,

(山本)

ゼラチンの跕度 ゼラチンは其の原料の種類製遥法 の如何に係はらず $\mathrm{pH} 4.7$ 以下の酸性溶液に於ては 
$\mathrm{pH}$ 2.5 2.6 に於て最大の粘度か有寸 $\mathrm{pH} 4.7$ 以上 のアルカリ性溶液に於ては製造に際してアルカリ處理 したっいのは一般に pH 5.5 附近に於て最小粘度方示 し其の後 $\mathrm{pH} 9.0$ 附近までは大なる變化なし又 $\mathrm{pH}$ 9.0 以上に於て粘度甚げ賭大するるのもあり而して $\mathrm{pH}$ 2.5〜2.6 に於て示す最大粘度の大なろるの程概して平 均粘度高子な見万又短暗間比較的高溫度に加熱す万る 粘度に變化㤂來さず粘度測定に當りて $25^{\circ} \mathrm{C}$ 附近はゼ ラチンのゼリーに變ずろ轉移點附近なるによりこの㳢 度にて行子時は不定な万結果右與子ろに依り $40^{\circ} \mathrm{C} に$ て行及伖可とす (Clarke E. Davis and Henry M. Salisbury, Ind. Eng. Chem., 1928, 20, 829)

$$
\text { (山本) }
$$

ファット・リカーに卵黄の使用 ファット・リカーを

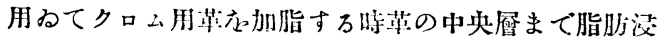
透せず而してスルフォン化油のみ方倪用する時は脂肪


万に從って肉面侧に多量の脂肪入り遂に卵簧のみ死使 用す万時は反跱の結果右示すこの現象はスルフォン化 油の乳爿液は卵兴教加へたるものよりも甚げ微細なる 分散ななす事に起因するが如し（Henry B. Menill, Ind. Eng. Chem., 1928, 20, 654)





142

324

们張 度 \%





-

0.4

-

3.4
(山本)


一方か植物タンニン鞣、他方かクロム・タンニン混合粲 它行ひ底勒后作り其の重量、面積、收率、價格、厚さ、 密度、抗張力、伸張度及び化學的成分方此輘せ $り$ 其の 平均值次の二表の如し

\section{植物タン 混 合 鞣
$=$ 鞣}

重 量 $\left\{\begin{array}{lrr}\text { 生皮(ボンド) } & 25.00 & 24.75 \\ \text { 仕上ド) } & 16.50 & 10.00 \\ \text { 此(\%) } & 66 & 40\end{array}\right.$

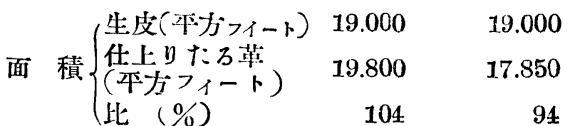

比率 面穔(不方フィート) $79 \quad 71.5$

40

$\begin{array}{lll}\text { 1年方フートの重 } & 0.84 & 0.56 \\ \text { 量(ポンド) }\end{array}$

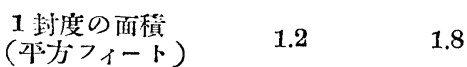



輕

0.145

0.704

100

257

27.5

7.7

2.5

62.7

22.1

1.4

0.2

1.2

0.1

3.8

$-$

3.0

-

3.2

2.7



0.152

0.184 :

0.720

0.827

$88 \quad 94$.

$224 \quad 193$

$26.0 \quad 24$

$\begin{array}{ll}7.9 & 7.9\end{array}$

$1.7 \quad 2.1$

63.2

46.0

20.1

32.2

3.7

9.8

5.9

3.9

2.3

0.3

2.4

3.7

$-$

2.0

1.1

2.7 
但し植物タンニン劑としてはケブラコ、チェスナッ ト、檞等方主として使用しクロムは一浴法る使用せり (R. W. Frey, I. D. Clarke and L. R. Leinbach, J. A. I. C. A., 1928, 13, 430)

（永 润）

鹽皮及其の䟞留法 15〜16\%（重量）の食監方含有 する $60^{\circ} \mathrm{F}$ 溶液 100 がロンに狱酸加里 3.5 ボンド、 重曹 4.0 ポンド、硫酸曹迋 2.0 オンス、フォルマリン 1.5 パイント死加一皮を 15 分間これに浸漬したる後


の溶解バクテリヤの作用定減少し其止りの良奵なる等 の利點おり (E. P. Eaton. Hide and Leather, 1928, 75, No. 13, 14)

(永 岡)

植物蔡苹に對する酸の影警 $10 \%$ 各種の酸虑華の 10 倍重量仗用し 2 ケ月間渗漬して後乾燥し莯張力右

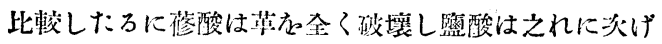


前同樣にして葆酸㤂除外して其の作月は $\mathrm{pH}$ の減少に

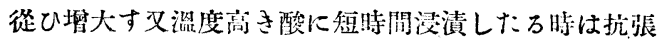

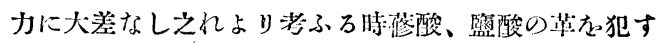


後漼所に 6 ケ月放置したるものは一規定の苳酸より




中に殘ろ時は甚だ危險なるものなり (D. Woodroffe, J. I. A. L. T. C., 1928, 12, 385)

\section{(永 岡)}

ファット・リカーの顯徽鏡による研究 各喠の乳濁劑 にて孚濁液子作り顯微鏡下に置き又其の $\mathrm{pH}$ 傮々測 定し微粒子の大きさ、算圈の有無、ブラウン氏荤動の 有無、 $\mathrm{pH}$ 價に起因す万安定度、又乳濁液の状態方研

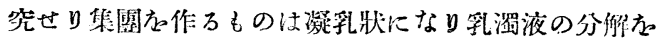
來しアルカリの添加は微粒子の娍少叴來し渄透となす 但し微䊀子の形狀に變化尗與へずこの原因は表面張力 の增加に依万ものにして酸右加ふ万時は孚濁㤬起火小 分散力は表面張力に關係なくスルフォン化油の時の分 散力は $(\alpha+\beta: \gamma)$ に從ふ但し $\alpha 、 \beta$ 及び $\gamma$ は脂肪 酸、酸化脂肪酸と硫酸化さ万酸及び中性油の量方表す (W. Schindler, Collegium, 1928, 12, 693)

\section{(永 岡)}

\section{2. 爆發物及燐寸}


のね更に種々なろ割合に溶劑と混じ爆藥の溶解ささろ
液中に挖垀しつ〉注加す例へばテトラントロペンタエ リスリット及テトリールをアセトンに溶解したる後水 中に投じて粒狀となすことね得 (O. Mitter, B. P. $29660025,11,27$ )

(狗喰)




に酸素を發すれど $112^{\circ} \mathrm{C}$ に至れば遊離酸素のために 完全に烈し、爆發す又アルコール、タール、鎪油或は 澱粉の如き有機物との混合物は常涴にては安定なれど

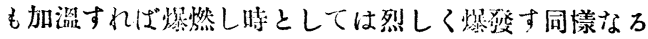
絬果は水分と拚解するときにも得られたりされど此の 場合には有機物の性質に依り作用に多少の時間家要す (J, Weichherz, Clbem. Ztg., 1928, 52, 729-730)

(狗喰)

T. N. T. の製造 $80-95^{\circ} \mathrm{C}$ にて筈したろヂニト ロトルオールが $86^{\circ} \mathrm{C}$ となりたるとき反應罣度 $95^{\circ} \mathrm{C}$


て确化す本确化は 3-4 時間にて完結す例一は熔融ヂ= トロトルオール $1000 \mathrm{~kg}$ 存 $80^{\circ} \mathrm{C}$ に於て發煙硫酸 $(20$ $\% \mathrm{SO}_{3}$ ) $2665 \mathrm{~kg}$ 、确酸 ( $\left.48^{\circ} \mathrm{Bé}\right) 704 \mathrm{~kg}$ なる混酸中に 㩭拌しつつ加ふれば T. N. T.は $100 \mathrm{~kg}$ 名生ず製品 は 77-79 $\mathrm{C}$ の融點有有す（A.-G. Lignose, B. P. 294625, 1928. 2. 13.)

(才才 喰)

ニトログリセリン、ニトログリコール及び其の同族

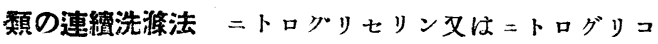




くり沙滌不可能なれば乳濁徐々に通過せしもべき除渣 譏叴供ふ万裝置か有效とす（A. Schmid and J. Meissner, B. P. 284702, 1928. 1. 28)

（才才喰）









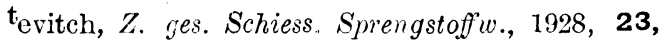
156-157)

(狗喰)




せず殊に機械的衝篧か加ふることに於て然り（C. Bunge, Z. ges. Schiess. Sprengstoff $w .$, 1928, 23, 44)

（犲喰）

\section{火烈の爆墢溫度と其の然燒率との關係 ニトログリ} セリンと綿火燕の等量にセントラリット0-15\%含 
屯火燕の燃燒率の對數は爆發溫度り直楾函數な $\mathfrak{y}(\boldsymbol{H}$. Muraour, Compt. rend., 1928, 187, 289-290)

（狗 喰）

\section{3. 食品化 學}

乳の錮含有量 牛乳、山洋乳、羊乳及び牛乳製品中 の銅方 サップレー、ベリス雨氏法（J，Dairy Sci， 1922，5，455）に依つて测定せ万絬果

\begin{tabular}{|c|c|c|}
\hline & 1l山のmg量 & 同平均 \\
\hline 牛 乳 & $0.26-0.52$ & 0.41 \\
\hline 羊 乳 & $0.45-0.50$ & 0.48 \\
\hline 山羊乳 & $0.19-0.25$ & 0.21 \\
\hline 殺菌学乚 & $0.60-1.60$ & 1.11 \\
\hline 酪 乳 & $2.40-2.50$ & 2.45 \\
\hline 棟，笔乚 & $1.80-2.70$ & 2.15 \\
\hline
\end{tabular}

牛乳製品に銅量多きは銅裴管器に掕觸するが篇なり (G. N. Quam and A. Hellwig, J. Biol. Chem., 1928, 78, 681)

(高 田)

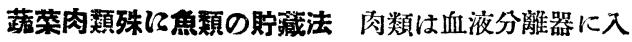


中熱風乾燥方なし鐫に入れ油店以て被ひ最後に殺菌す (M. Avanzi, F. P. 636325 , 1928, 6. 4.)

$$
\text { (高 田) }
$$

野荣、果害の處理法 保存すべき䐠栄等龙先ず 4-8 部の $\mathrm{Na}_{2} \mathrm{HPO}_{4}$ の如きアルカリ性溶液中 $\mathrm{pH}=7.0$ -

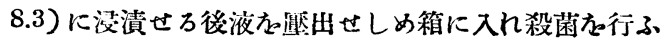
斯くすれば唡㭉等の天然の色彩方保有せしもる在得 (J. B. Butler and J. J. Drumm, U. S. P. 1666551 1928, 17. 4.)

(高 田)


ろ時はその不快なる味及び思氣死失ひ食品として用ひ 得ろるのとなる (A. Cartier u. P. Gloess, F. P. 633696. 1928, 2. 2.)

(高 田)

海産食品の㮡偠 (III) 蛤のヴィタミン 蛤 $(V e$ nus mercenaria 妓びおほのがい (Mya arenria) 中


タミンBは殆んど含有せず新鮮肉 $5 \mathrm{~g}$ 或は乾燥物 $5 \mathrm{~g}$ る與ふ万も何等の数果方認めずヴィタミンA は雨者共 数力强了乾燥眼炎治癒に恐す万最少量は蛤に於て $5 \mathrm{~g}$ 大野貝に於て $3.5 \mathrm{~g}$ 位にあり雨者は又相當のヴィタミ


に15 日にて完全に石灰化す万認む蛤及び大野貝は 又繁殖に必渠な万ヴィタミンE も相當に含有すこの結 果㤂先に著者等が牡螈に就て得し結果 (本誌、31, 10


蛤には含有せずヴィタミン $\mathrm{A}$ 效力に於ても蛤は轮螨よ りし稍劣ろが如きもヴィタミンD 並にヴィタミンE 效 力に就て勝れり (D. B. Jones, E. M. Nelson and J. C. Murphy, Ind. Eng. Chem., 1928, 20, 648)

\section{酸素等の殺藻法 ヂアスターゼの如き殺菌すべき物}


て光源としては水銀ランプ念用び光線の通過方向面か


て光線虑滤過して用子(D. Laurence, U. S. P. 1676579. 1928, 10. 7.)

（高田）

冷藏室に貯䋐する肉類の包装 肉類の包装に用ふ万


冷却後更に布片各石灰の如無害殺菌效果各有す万溶 液中に淩し再び畭懆して用ふ(A. R. McLeod, Aust. p. $8285,1928.1)$

（高 田）

\section{チョコレートより成る物啠等より人造果實の製法}

錫簿にて包みたる材料后柔靱なる䇴よりなる着色膜に


の際天然果實の色澤后得せしも万目的に一箈の外部又


1928. 11. 2.)

(高 田)

食品としての大豆粉 大豆枌な $10 \%$ 支び $20 \%$ 加人 たろ小麥粉にて製したるパンに就き消化吸收試驗龙行 ひたろ結果之等の消化吸收率は全固形分 93.7 及び 92. 4\%、總カロリー93.8 及び $92.5 \%$ 、合堂素物 83.9 及 び 80.3\%、脂肘 94.1 及び $95.7 \%$ 、含水炭素 96.6 及 び $97.0 \%$ 、灰分 68.6 及び 62.5\%にして夫々上等及び 中等小麥粉パンの吸收率に相䈏寸人工消化法に依れ代 消化卒は大転蛋白に於て $95.0 \%$ 、款粉に於て $94.3 \%$ な り大豆粉の脱脂は消化率に著しき影響なし大至は人類 の食糞として推和すへききのなりとす（V. Duccheschi. Arch. fisiol., 25, 428; Chem. Zentralb. 1928, II, 115)

(高田)

純粹るる $\boldsymbol{l}$ ープロリンの分襍 蛋白質分解物中の> ミノ酸右銅監としその溶解性により 3 區分寸即ち (1) 水及びメチルアルコールに溶けるをの（2)水に溶けメ チルアルコールに不溶なるもの（3）共に不溶なるも の(1)に蜊するものはブロリン、ヴァリン、七ドロキシ ヴァリン等にして之等の銅暨より銅る除けろ後純アル コールにて處理すればプロンンのみ溶解するが故に之

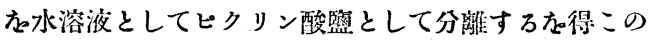
方法は蛋白分解物中ょり殆んど定量的にプロリンな分 
離し得ろものなり純プロリンは冷無水アルコールには 溶け難きも溻もればよく溶解寸又水溶液より結晶せし め得比旋光度は從來の测定數字よりし高くして $[\alpha]_{D}^{18}$ $=-86.7^{\circ}$ なり (B. W. Town, Biochem. J., 1928, 22, 1083)

(高田)

ハロゲン化蛋白質 (IX) クロル卵蛋由 乾燥粉末 畉蛋白な $\mathrm{Cl}_{2}$ の $\mathrm{CCl}_{4}$ 溶液にて長く處理して $\mathrm{Cl}_{2}$ 17.5\%ふ合めろク口ロ卵蛋白る得だり水及び $\mathrm{NaOH}$ 液 にて强く分解せらろクロロ及びグロム卵蛋白中の八ロ ゲンの量とクロロ及びグロムフォブリン中の八ロゲン の量とは是等八ロゲンの原子係數の比に等しクロロ文 びブロムカゼインとクロロ及びブロムグルテンとに對 しては此の比は $\mathrm{Cl} 2$ 原子に對し $\mathrm{Br} 1$ 原子なり即 ち恐らく分子化合物か生ず万ものと考へらろ(Alb. J. J. Vandevelde, Rec. truv. Chim., 1928, 47, 458)

(宇 野)

\section{4. 分 析 化 學}


Abst., 5, 1888) 方詳細に實驗し炭素の含有量 1\%以 下の場合にのみ用ひらろ 補正を見出しだ（N.M. Miloslavski \& V. F. Vepritzkii, Ukrainskii Khem. Zhurnal, 1928, 3, No. 1, tech. pt., 31-5)

(牙 喰)

\section{理需の比色定置に人造標準色としてビクリン酸の利}


énert \& Wandenbulcke 法 (Analyst, 1923, 48, 3 98）により試驗せし結果 11 につき珄酸 $0.05 \mathrm{~g}$ 吕含む 液の黃著色の强度は 17 につきビクリン酸 $0.0256 \mathrm{~g}$ ね 含む液に相當することな示さり耏して本試驗に供する ピクリン酸は異空乾燥の純化學用品なり (E. J. King \& C. C. Lucas, J. Amer. Chem. Soc., 1928, 50, 2395-2397)

(牙喰)

マグネシウムの銳敏呈色及應 $1 l$ に $0.5 \mathrm{mg}$ な溶解 しホろマグネシウム跋溶液 $100 \mathrm{cc} に 0.1 \%$ クレイト ン黃溶液 $0.2 \mathrm{cc}$ と $4 N^{\top}$ 苛性曹達溶液 $0.5 \mathrm{cc}$ な加人 たろときは鮮橙色な゙旺すれど 11 に $5 \mathrm{mg}$ 以上な溶解 せし液は煉瓦赩死呈す又 $1 l$ に $300 \mathrm{mg}$ のカルシウ 么正溶解したるものは何等影響な與へざるもそれ以上 なるときは乳光色走星す (H. D. Barnes, J.S. Afr. Chem. Irist., 1928, 11, 67-68)

(软 喰)

銀に銃敏はる新學とその試驗法 カーヂメチールア ミノベンヂルヂンローダニン、 $\mathrm{AgC}_{12} \mathrm{H}_{11} \mathrm{~N}_{2} \mathrm{OS}_{2}$ の 銀監は酸性、中性又はアンモニア性銀液に陚液（ロー
ダニン基 $0.03 \mathrm{~g}$ ねアセトン $100 \mathrm{cc}$ に溶解さしも の）加ふれぱ赤紫色絮狀沈澱として生ず銀の濃度極 めて僅少なるときは沈澱は褐色にして遊離監基名含有 すされば微量なる銀を定量さんには溶液なェーテル、

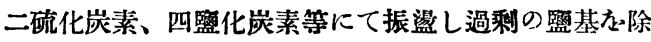
去さざろべからずこの際ローダニン監基は可溶にて銀 監は絕對に不溶なり本反應の 銳敏度は最小限度 $1: 5$. 000,000 なり又本反應は鑛物、金屬及監数中の微量银 な检出するに用ひらろ例人は货幣白金等に会有さらる 〉银監は可檢物叴素燒板上にのさその上に一湤の矿酸 そ加一酸の過剩在素燒板方下部より加溫して除去し口 一ダニン監基のアセトン溶液中に浸漬せば銀監存在す ろときは酸にて應蝕せられし點に赤紫色龙顯すなり若 し水銀附准するときは此の操作の前に强熱してこれる


C. S., 1877, 2, 872; Holmberg, Brit. Chem. abst., 1906，1，811）及 $p$-ヂメチルアミノベンザルデハ1 ドの等分子混命物を還流冷却器か。用ひ 1 時問水醋酸と 者沸し縮合物石水にて沈澱せしめ堂沸しアルコールに て再絬晶せしぬて調製す(F. Feigl, Z. anal. Chem.， 1928, 74. 380-386)

(才哪)

チオシアン酸加里による鐵の比色定量法 水中の鐵 な定量す万 Dutch Codex 法の改长として可檢液に


の監類存在さろにしか〉わらず $1000 \mathrm{cc}$ 中 $0.1 \mathrm{mg} の$ 鐵方检出し得此の場合可液中の鐵方第二鐵監の狀㑷に 酸化するに過硫酸加里方用ふれば有效なり（L. S. v. D. Vlugt, Chem. Weekblad, 1928, 25, 495-496)

(犲喰)

\section{數種の無機弗化物の $25^{\circ} \mathrm{C}$ の水に對する溶解度 弗} 化物を農作物の殺䖵劑として使用寸万場合溶解度餘り に大なろものは矛弱なる植物の莱る枯死さしむろのみ ならず又雨露の焦溶解し去万票あり之に反し溶解度極 小なろ時は害䖵に對し有毒作用な呈さざる缺點あり既 に他の研究者に依りて報告せられたる結果な見ろに種 々なる溫度に於け万溶解度に著しき差異おり苩者は之 等文献に記载さられたろ方法に依り調製せる 16 種の 金曆弗化物の純度 $99 \%$ ののね使用して $25 \pm 0.1^{\circ} \mathrm{C}$ に於ての溶解度か測定せり、份弗素合有量及び館和溶 液の $\mathrm{pH}$ 儥わし測定し之等々總括して表示し前記他 の研究者の報告に依万溶解度の表と比較せり（R，H. Carter, Ind. and Fng. Chem., 1928, 1195)

(定方) 